\title{
Food Insecurity and Mental Health among Females in High-Income Countries
}

\author{
Merryn Maynard 1,*, Lesley Andrade ${ }^{2}$, Sara Packull-McCormick ${ }^{2}$, Christopher M. Perlman ${ }^{2}$, \\ Cesar Leos-Toro ${ }^{2}$ and Sharon I. Kirkpatrick ${ }^{2, *}$ (iD \\ 1 Meal Exchange Canada, Toronto, ON M5V 3A8, Canada \\ 2 School of Public Health and Health Systems, University of Waterloo, Waterloo, ON N2L 3G1, Canada; \\ landrade@uwaterloo.ca (L.A.); srpackul@uwaterloo.ca (S.P.M.); chris.perlman@uwaterloo.ca (C.M.P.); \\ cesar.leos-toro@uwaterloo.ca (C.L.-T.) \\ * Correspondence: merryn@mealexchange.com (M.M.); sharon.kirkpatrick@uwaterloo.ca (S.I.K.); \\ Tel.: +1-416-657-4489 (M.M.); +1-519-888-4567 (ext. 37054) (S.I.K.)
}

Received: 5 June 2018; Accepted: 4 July 2018; Published: 6 July 2018

\begin{abstract}
Food insecurity is a persistent concern in high-income countries, and has been associated with poor mental health, particularly among females. We conducted a scoping review to characterize the state of the evidence on food insecurity and mental health among women in high-income countries. The research databases PubMed, EMBASE, and psycINFO were searched using keywords capturing food insecurity, mental health, and women. Thirty-nine articles (representing 31 unique studies/surveys) were identified. Three-quarters of the articles drew upon data from a version of the United States Department of Agriculture Household Food Security Survey Module. A range of mental health measures were used, most commonly to measure depression and depressive symptoms, but also anxiety and stress. Most research was cross-sectional and showed associations between depression and food insecurity; longitudinal analyses suggested bidirectional relationships (with food insecurity increasing the risk of depressive symptoms or diagnosis, or depression predicting food insecurity). Several articles focused on vulnerable subgroups, such as pregnant women and mothers, women at risk of homelessness, refugees, and those who had been exposed to violence or substance abuse. Overall, this review supports a link between food insecurity and mental health (and other factors, such as housing circumstances and exposure to violence) among women in high-income countries and underscores the need for comprehensive policies and programs that recognize complex links among public health challenges.
\end{abstract}

Keywords: food insecurity; mental health; depression; women; scoping review

\section{Introduction}

Food insecurity is a growing and persistent concern in high-income countries [1,2]. In North America, rates of household food insecurity have remained stable or risen in the last several years $[3,4]$. High rates have also been documented in the UK and Australia [5,6]. According to the Food and Agriculture Organization, "food security exists when all people, at all times, have physical, social, and economic access to sufficient safe and nutritious food that meets their dietary needs and food preferences for an active and healthy life" [7].Conceptualizations of food insecurity in high-income countries primarily focus on the economic aspect; for example, the Household Food Security Survey Module (HFSSM) [8], which is commonly used in the United States and Canada, measures uncertain or inadequate access to food due to financial constraints. This conceptualization aligns with literature linking vulnerability to food insecurity to high rates of poverty, particularly among population subgroups, such as single-parent households, racial/ethnic minorities, and those relying on social assistance [2-4,9-13]. 
Among population subgroups in high-income countries, food insecurity has been shown to be associated with compromised nutrition [14], poor general health, and a myriad of chronic health conditions $[15,16]$. Food insecurity has also been shown to be a marker of poor mental health, with studies identifying associations with mood and anxiety disorders and suicidal ideation, particularly among women [16-18]. Indeed, severity of household food insecurity appears to be linked with poor mental health in a dose-response manner, with experiences of severe food insecurity representing extreme chronic stress [19] and possibly acting as an independent determinant of suicidal ideation [20].

The relationship between food insecurity and poor mental health among women is of particular concern given that they are disproportionately impacted by food insecurity [2-4,21]. Women are overrepresented among low-income groups compared to men, with visible minority women and single mothers experiencing high rates of poverty in Canada and the United States [9-11]. Further, the existing literature suggests that women may be particularly vulnerable to poor mental health in conjunction with poverty and food insecurity [12] and for women with children, that the stress associated with these experiences has possible ripple effects, negatively impacting their children's physical and mental health as well [13].

To identify future research needs and inform policy and program responses, we conducted a scoping review to examine the state of the literature on food insecurity and mental health among women living in high-income countries.

\section{Materials and Methods}

The scoping review was conducted according to steps outlined by Arksey and O'Malley [22]. Scoping reviews, which use systematic search techniques, are appropriate when the aim is to address a broad question, such as querying the state of the evidence on a topic (especially when study designs may vary) and identifying gaps in that evidence [22] to inform future research and practice. As per Arksey and O'Malley [22], steps in the process include identifying the research question, identifying relevant studies, study selection, charting the data, and collating, summarizing, and reporting the results. Reporting follows the PRISMA guidelines [23].

\subsection{Identifying Relevant Studies}

The systematic search, developed in consultation with a librarian who is an expert in systematic searching, was conducted using the research databases PubMed, EMBASE, and psycINFO to capture records published up to May 2016. Given the range of possible mental health conditions, the search strategy was quite broad. Key words and Medical Subject Headings (MeSH) included "food" OR "nutrition" OR "diet" AND "security" OR "insecurity" OR "insufficiency" OR "scarcity" OR "*adequacy" OR "hunger" OR "poverty" OR "food supply" OR "nutritional requirements/status" AND "anxiety" OR "depression" OR "mental health" OR "mental health disorder" OR "mental health illness" OR "psychosis" OR "emotional disorder" OR "mania" OR "mental disease" OR "phobia" OR "mental disturbance/health/psychology". The key words and MESH headings to capture women included "women" OR "woman" OR "female" OR "pregnancy" OR "sex factors" OR "women's rights" OR "mothers" OR "girl" (note: * indicates a wildcard, which allows searching a range of terms related to a root word). The initial search elicited a total of 13,645 citations (excluding duplicates) (Figure 1). 


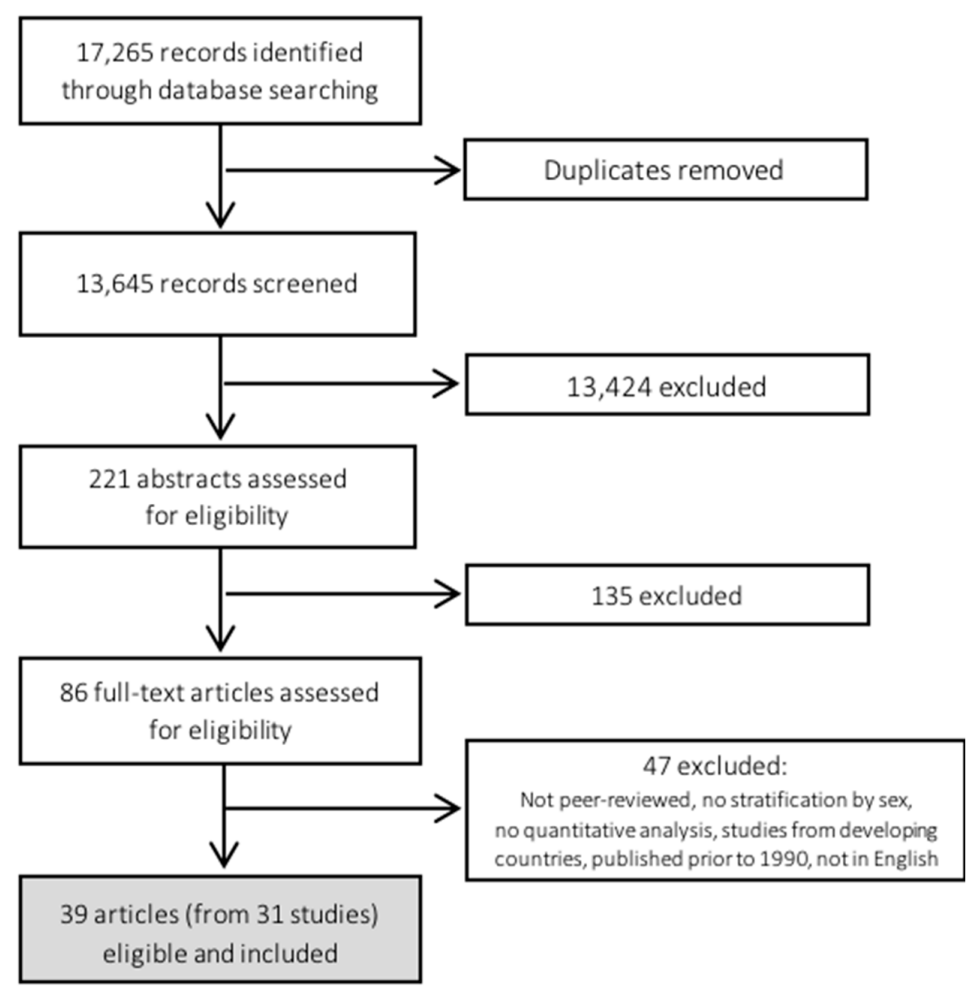

Figure 1. Overview of identification and screening of records for scoping review of literature on food insecurity and mental health among women in high-income countries.

\subsection{Study Selection}

Articles deemed eligible quantitatively examined associations between food insecurity and indicators of mental health, with a focus on females in high-income countries; studies that included both males and females but reported analyses stratified by sex were also considered. Specific criteria related to age were not applied, allowing consideration of studies reporting on adolescent girls as well as women. Studies published since 1990 (to provide insights into relatively recent research on the topic of food insecurity) were considered.

An initial screening of titles and abstracts was conducted by one author (S.P.-M.) to identify potentially relevant peer-reviewed articles that addressed food insecurity and health, leaving 221 citations for further review (Figure 1). Abstracts for these 221 citations were screened independently by a second author (M.M. or S.I.K.) and discrepancies resolved, leaving 86 citations for full-text review. After full-text screening (conducted independently by two authors), 39 articles remained, representing 31 unique studies/surveys. Separate articles making use of data from the same study or survey were examined and charted to identify salient characteristics related to measurement of food security and mental health and the examination of associations between the two.

\subsection{Charting the Data}

A data abstraction form guided extraction of the characteristics of interest, including study setting and population, study design, main study objectives, measures used to assess food security and mental health and specific mental health states considered, and analytic approach and findings.

\subsection{Collating, Summarizing, and Reporting the Results}

The abstracted data were assessed in terms of patterns in measures and tools used and associations between food insecurity and depression (the most frequently examined mental health measure) and other mental health markers. Given that we conducted a scoping rather than a systematic review, 
formal quality appraisal of studies was not conducted [22]. However, in addition to synthesizing the evidence emerging from this literature, we comment on the characteristics of the available research, in terms of study design for example, to inform future research.

\section{Results}

\subsection{Overview of Included Articles}

The characteristics of the 39 articles are outlined in Appendix A. Over half $(n=23)$ were published from 2010 on [15-17,24-43]. The majority $(n=34)$ analyzed data from studies conducted in the United States, three focused on studies conducted in Canada [16,17,32], one was focused on a sample in New Zealand [43], and one was conducted in England [44]. Twenty-eight articles reported on cross-sectional analyses (one also included qualitative data collection [28]) and eleven reported longitudinal analyses (one included qualitative data collection [45]) (Appendix A). Although all studies assessed the association between food insecurity and a mental health condition or state in some manner, the particular research questions and analytic approaches varied. Some studies examined food insecurity and mental health among general samples of the population, whereas others focused on particularly vulnerable population subgroups or sought to assess the feasibility or other properties of tools. Half $(n=20)$ focused on mothers or caregivers, another five studied pregnant women, and several focused on other specific subpopulations, including rural women, those living with disabilities, older women, refugees, women experiencing insecure housing or homelessness, and women at risk for HIV (Appendix A).

\subsection{Food Insecurity Measures}

Three-quarters $(n=30)$ of the reviewed articles drew upon data collected using a version of the Household Food Security Survey Module (HFSSM), developed by the United States Department of Agriculture [8] (Table 1). The full HFSSM contains 18 items and yields a single score indicating the severity of household food insecurity over the past 12 months or 30 days; ten items refer to adults and eight refer to children in the household [8]. Scores are typically used to categorize households as food secure or food insecure with different levels of severity (since a review of the measure conducted in the early 2000s [46], the categories of food insecurity have been referred to as low and very low food security, replacing earlier labels of food insecure with/without hunger). The HFSSM was compared to household food expenditures and income [8] and associated with compromised dietary intakes [14], supporting its validity in capturing constrained food access due to inadequate finances. Fourteen articles drew upon abbreviated versions of HFSSM, including the six-item subset developed by USDA and the ten adult-referenced items, as well as other adaptations (Table 1).

One article reported on data using a single item drawn from the 12-item Radimer-Cornell scale [47], and another used data collected using the Community Childhood Hunger Identification Project (CCHIP) instrument [48]. Both the Radimer-Cornell and CCHIP tools are used to categorize food security status and were shown to have good specificity and sensitivity compared to evaluations of food security status based on household food inventories, dietary recall data, and other measures among a sample of women living with children in rural New York [49]. These tools were drawn upon in the development of the HFSSM [8].

Three articles drew upon data collected using a single item from the National Health and Nutrition Examination Survey-III (NHANES-III) to assess food insufficiency (defined as "an inadequate amount of food intake due to a lack of money or resources") [50]. As opposed to more comprehensive instruments, measures of food insufficiency are less detailed and may misclassify some households [49,51]. Finally, four articles drew upon data from other single- or multi-measures adapted from prior literature (Table 1). 
Table 1. Overview of measures of food security drawn upon in articles $(n=39)$ examining associations between food insecurity and mental health among women in high-income countries.

\begin{tabular}{|c|c|c|c|c|}
\hline Measure & Description & $\begin{array}{l}\text { Abbreviated and Modified } \\
\text { Versions }\end{array}$ & Articles Using Full Version & $\begin{array}{l}\text { Articles Using Modified } \\
\text { Versions }\end{array}$ \\
\hline $\begin{array}{l}\text { Community } \\
\text { Childhood Hunger } \\
\text { Identification Project }\end{array}$ & $\begin{array}{l}\text { An 8-item scale developed by Wehler et al. [48]. Part of a } \\
\text { survey instrument to examine the prevalence of hunger } \\
\text { among low-income families. The items address qualitative } \\
\text { and quantitative compromises among adults and children. } \\
\text { Shown to have good specificity and sensitivity compared to } \\
\text { evaluations of food security status based on household food } \\
\text { inventories, dietary recall data, and other measures among a } \\
\text { sample of women living with children in rural New York [49]. }\end{array}$ & None & None & Wehler et al. 2004 [52] \\
\hline $\begin{array}{l}\text { Household Food } \\
\text { Security Survey } \\
\text { Module }\end{array}$ & $\begin{array}{l}\text { An 18-item measure developed by the United States } \\
\text { Department of Agriculture [8] and used to monitor household } \\
\text { food security in the US and Canada. Measures the food } \\
\text { security status of a household in the last } 12 \text { months. Items ask } \\
\text { an adult respondent about anxiety related to the household } \\
\text { food supply, running out of food, providing inadequately } \\
\text { nutritious food, and substitutions or restrictions in food } \\
\text { consumption by adults and/or children in the household due } \\
\text { to lack of financial resources. Items are compiled to form a } \\
\text { continuous, linear scale that categorizes households into one } \\
\text { of four groups; food secure, marginal food secure, low food } \\
\text { secure, and very low food secure [8]. Data from the HFSSM } \\
\text { have been compared to household food expenditures and } \\
\text { income [8] and dietary intakes [14], supporting its validity in } \\
\text { capturing constrained food access due to inadequate financial } \\
\text { resources. }\end{array}$ & $\begin{array}{l}\text { Six-item short form: uses a } \\
\text { subset of the 18-item survey. } \\
\text { Does not characterize severe } \\
\text { food insecurity and does not } \\
\text { contain child-specific items. } \\
\text { 10-item adult scale: includes } \\
\text { only items referenced to } \\
\text { adults in the household. } \\
\text { Health Canada modifications: } \\
\text { Refers to low food security as } \\
\text { "moderate food insecurity" } \\
\text { and very low food security as } \\
\text { "severe food insecurity". Less } \\
\text { stringent than USDA coding, } \\
\text { in that } 2+\text { affirmative } \\
\text { responses place an individual } \\
\text { into a food insecure category. }\end{array}$ & $\begin{array}{l}\text { Bronte-Tinkew et al. 2007 [53]; } \\
\text { Casey et al. 2004 [54]; Chilton } \\
\text { et al. 2013 [28]; Corman et al. } \\
\text { 2016 [24]; Garg et al. 2015 [25]; } \\
\text { Hanson et al. 2012 [15]; } \\
\text { Hernandez et al. 2014 [26]; } \\
\text { Huddleston-Casas et al. 2009 } \\
\text { [55]; Laraia et al. 2006 [56]; } \\
\text { Laraia et al. 2015 [27]; } \\
\text { Lent et al. 2009 [45]; McCurdy } \\
\text { et al. 2015 [29]; Sun et al. } 2016 \\
\text { [30]; Trapp et al. } 2015 \text { [31] } \\
\text { Health Canada coding: } \\
\text { Muldoon et al. 2013 [32]; } \\
\text { Tarasuk et al. 2013 [16] }\end{array}$ & $\begin{array}{l}\text { Dressler et al. } 2015 \text { [37]; Kaiser } \\
\text { et al. 2007 [57]; Laraia et al. } 2009 \\
\text { [58]; Martin et al. 2016 [17] } \\
\text { (Health Canada coding); } \\
\text { Mathews et al. } 2010 \text { [34]; } \\
\text { Peterman et al. } 2013 \text { [38]; } \\
\text { Sharpe et al. 2016 [39]; Whitaker } \\
\text { et al. 2006 [59]; } \\
\text { 15-item adaptation for pregnant } \\
\text { Latinas: Hromi-Fielder et al. } \\
\text { 2011 [36] } \\
\text { Other non-standard adaptations } \\
\text { (3-, 4-, or 7-items): Ajrouch et al. } \\
\text { 2010 [35]; Davey-Rothwell et al. } \\
\text { 2014 [40]; Harrison et al. 2008 } \\
\text { [60]; Melchior et al. 2009 [44]; } \\
\text { Sidebottom et al. 2014 [33] }\end{array}$ \\
\hline $\begin{array}{l}\text { National Health and } \\
\text { Nutrition Examination } \\
\text { Survey-III } \\
\text { (NHANES-III) food } \\
\text { sufficiency indicators }\end{array}$ & $\begin{array}{l}\text { NHANES-III was a health and nutrition survey conducted by } \\
\text { the US Center for Disease Control (CDC). A food sufficiency } \\
\text { component was included in the in-home adult questionnaire. } \\
\text { Respondents were classified as "food insecure" if they } \\
\text { "sometimes" or "often" did not have enough food to eat. } \\
\text { Other questions included how many days in the prior month } \\
\text { the respondent did not have money for food, reasons for not } \\
\text { having enough food, and whether the respondent or child in } \\
\text { the household had restricted their food intake due to lack of } \\
\text { food [61]. }\end{array}$ & None & $\begin{array}{l}\text { Heflin et al. } 2005 \text { [62]; Siefert } \\
\text { et al. } 2007 \text { [63]; Siefert et al. } \\
2001 \text { [64] }\end{array}$ & None \\
\hline
\end{tabular}


Table 1. Cont

\begin{tabular}{|c|c|c|c|c|}
\hline Measure & Description & $\begin{array}{c}\text { Abbreviated and Modified } \\
\text { Versions }\end{array}$ & Articles Using Full Version & $\begin{array}{c}\text { Articles Using Modified } \\
\text { Versions }\end{array}$ \\
\hline $\begin{array}{l}\text { New Zealand measure } \\
\text { of individual } \\
\text { deprivation (NZiDep) }\end{array}$ & $\begin{array}{l}\text { An 8-item scale measuring individual socioeconomic } \\
\text { deprivation, specific to New Zealand. The scale has been } \\
\text { validated among Maori, Pacific, and White New Zealand } \\
\text { citizens [65]; criterion validity relied upon associations with } \\
\text { tobacco smoking. Includes three-item composite measure of } \\
\text { food security: "In the last } 12 \text { months have you personally } \\
\text { made use of special food grants or food banks because you } \\
\text { did not have enough money for food?" (yes/no), "In the last } \\
12 \text { months have you personally been forced to buy cheaper } \\
\text { food so that you could pay for other things you needed?" } \\
\text { (yes/no), "In the last } 12 \text { months have you personally gone } \\
\text { without fresh fruit and vegetables often so that you could pay } \\
\text { for other things you needed?" (yes/no). }\end{array}$ & & Carter et al. 2011 [43] & None \\
\hline Radimer-Cornell scale & $\begin{array}{l}\text { A 12-item scale developed by Radimer et al. [47] at Cornell } \\
\text { University based on qualitative research with low-income } \\
\text { women. Twelve items cover aspects of household, adult, and } \\
\text { child food insecurity. The content of the items address food } \\
\text { anxiety, monotony of diet, financial constraints, food } \\
\text { restriction, insufficient intake, and acquiring food in socially } \\
\text { acceptable ways [47,66]. Shown to have good specificity and } \\
\text { sensitivity compared to evaluations of food security status } \\
\text { based on household food inventories, dietary recall data, and } \\
\text { other measures among a sample of women living with } \\
\text { children in rural New York [ } 49] \text {. Further information about } \\
\text { the evolution of the instrument is available [67]. }\end{array}$ & Single item & None & Sharkey et al. 2011 [41] \\
\hline $\begin{array}{l}\text { Other Multi- or } \\
\text { Single-Item Measures }\end{array}$ & & & $\begin{array}{l}\text { Birmingham et al. } 2011 \text { [42]; } \\
\text { Klesges et al. } 2001 \text { [68]; } \\
\text { Sharkey et al. } 2003 \text { [69] }\end{array}$ & None \\
\hline
\end{tabular}




\subsection{Mental Health Measures}

Depression and depressive symptoms were the most prevalent mental health states assessed. Associations between food insecurity and depression were examined in 36 articles (Appendix A). Ten articles drew upon measures assessing clinical diagnoses, while the remainder relied upon self-reported symptoms.

Measures are described in Table 2, along with information about their validation. In reviewed articles, authors sometimes noted that measures have been tested for psychometric properties such as internal consistency, in some cases, in the context of the particular study (Appendix A). Data from the short form of the World Health Organization World Mental Health Composite International Diagnostic Interview (CIDI) [70] were drawn upon to establish a clinical diagnosis of depression or anxiety in six articles. To assess depressive symptoms, the Centre for Epidemiologic Studies Depression Scale (CES-D) [71] was used most frequently, drawn upon in 14 articles. For anxiety, one article drew upon data from Spielberger's Trait Anxiety Inventory [72] and another the Hopkins Symptom Checklist Subscale (HSCL) [73]. Some measures targeted specific life stages such as pregnancy and older age; for example, maternal depressive symptoms were assessed with the Kemper three-item screen [74] and the Edinburgh Postpartum Depression Scale [75], while depressive symptoms among older women were assessed using the Geriatric Depression Scale [76].

Various other mental health markers were measured, including perceived control over one's life, perceived stress, quality of life, self-esteem, mastery, general mental health, psychosis, substance abuse, post-traumatic stress disorder, and disordered eating (Appendix A). 
Table 2. Overview of measures of mental health drawn upon in articles $(n=39)$ examining associations between food insecurity and mental health among women in high-income countries.

\begin{tabular}{|c|c|c|c|c|}
\hline Measure & Description & Abbreviated Versions & Articles Using Full Version & $\begin{array}{c}\text { Articles Using } \\
\text { Abbreviated Versions }\end{array}$ \\
\hline $\begin{array}{l}\text { Center for } \\
\text { Epidemiologic Studies, } \\
\text { Depression Scale } \\
\text { (CES-D) }\end{array}$ & $\begin{array}{l}\text { A 20-item self-report scale measuring depressive symptoms in the } \\
\text { general population. Components assess depressed mood, feelings of } \\
\text { guilt and worthlessness, feelings of helplessness and hopelessness, } \\
\text { psychomotor retardation, loss of appetite, and sleep disturbance in } \\
\text { the prior week. Validity of the CES-D has been established through } \\
\text { correlations with self-reported measures, clinical scores for } \\
\text { depression, and other construct validity variables. Reliability and } \\
\text { validity has been demonstrated across diverse characteristics of } \\
\text { general population samples [71]. }\end{array}$ & $\begin{array}{l}\text { 10-item short form } \\
\text { 12-item short form }\end{array}$ & $\begin{array}{l}\text { Ajrouch et al. } 2010 \text { [35]; } \\
\text { Davey-Rothwell et al. 2014 [40]; } \\
\text { Dressler et al. } 2015 \text { [37]; Hanson } \\
\text { et al. 2012 [15]; Hromi-Fielder et al. } \\
2011 \text { [36]; Huddleston-Casas et al. } \\
2009 \text { [55]; Laraia et al. } 2006 \text { [56]; } \\
\text { Laraia et al. 2009 [58]; Lent et al. } \\
\text { 2009 [45]; McCurdy et al. } 2015 \text { [29]; } \\
\text { Siefert et al. 2007 [63] }\end{array}$ & $\begin{array}{l}\text { Bronte-Tinkew et al. 2007 } \\
\text { [53]; Garg et al. 2015 [25]; } \\
\text { Sharpe et al. } 2016 \text { [39] }\end{array}$ \\
\hline $\begin{array}{l}\text { Cohen's Perceived } \\
\text { Stress Scale (PSS) }\end{array}$ & $\begin{array}{l}\text { A 14-item self-report Likert scale that measures the degree of } \\
\text { unpredictability of the respondents' life and the degree to which the } \\
\text { respondent feels stress regarding these situations. Validated in young } \\
\text { adult and post-secondary student population, the PSS correlated } \\
\text { with physical and mental health related outcomes [77]. }\end{array}$ & $\begin{array}{l}\text { PSS-4 (4-item subset) } \\
\text { 10-item short form }\end{array}$ & Laraia et al. 2006 [56] & $\begin{array}{l}\text { Trapp et al. } 2015 \text { [31]; Laraia } \\
\text { et al. } 2015 \text { [27] }\end{array}$ \\
\hline $\begin{array}{l}\text { Diagnostic Interview } \\
\text { Schedule (DIS) }\end{array}$ & $\begin{array}{l}\text { A structured interview designed for non-clinicians to assess and } \\
\text { diagnose psychiatric disorders in respondents according to criteria in } \\
\text { the Diagnostic and Statistical Manual of Mental Disorders, Fourth } \\
\text { Edition (DSM-IV). The DIS has } 19 \text { diagnostic modules that cover } \\
\text { different types of mental disorders. Within each module, respondents } \\
\text { answer whether they have particular symptoms at the present, or } \\
\text { have experienced them in the past [78]. }\end{array}$ & None & Melchior et al. 2009 [44] & None \\
\hline $\begin{array}{l}\text { Edinburgh Postpartum } \\
\text { Depression Scale } \\
\text { (EPDS) }\end{array}$ & $\begin{array}{l}\text { A 10-item self-report scale used to measure risk of postpartum } \\
\text { depression in mothers within eight weeks of delivery. Items assess } \\
\text { feelings of guilt, sleep deprivation, lack of energy, suicidality, and } \\
\text { other general depressive symptoms experienced within the last } 7 \\
\text { days. Validity has been examined in a sample of postpartum mothers, } \\
\text { 6-weeks post-delivery, and compared with clinician diagnosis of } \\
\text { depression [75]. }\end{array}$ & 3-item short form & None & Birmingham et al. 2011 [42] \\
\hline $\begin{array}{l}\text { Geriatric Depression } \\
\text { Scale (GDS) }\end{array}$ & $\begin{array}{l}\text { A 30-item self-report scale that assesses depression in geriatric } \\
\text { populations ( } \geq 55 \text { years). Items assess motivation, self-esteem, } \\
\text { helplessness, mood, and agitation [76]. }\end{array}$ & 15-item short form & Klesges et al. 2001 [68] & Sharkey et al. 2003 [69] \\
\hline $\begin{array}{l}\text { Hopkins Symptom } \\
\text { Checklist Subscale } \\
\text { (HSCL) }\end{array}$ & $\begin{array}{l}\text { A 58-item self-report scale used primarily with psychiatric } \\
\text { outpatients, capturing five symptom dimensions including } \\
\text { somatization, obsessive-compulsive, interpersonal sensitivity, } \\
\text { depression, and anxiety [73]. Authors discuss a variety of studies in } \\
\text { which the validity of the HSCL has been evaluated. }\end{array}$ & None & Klesges et al. 2001 [68] & None \\
\hline
\end{tabular}


Table 2. Cont.

\begin{tabular}{|c|c|c|c|c|}
\hline Measure & Description & Abbreviated Versions & Articles Using Full Version & $\begin{array}{c}\text { Articles Using } \\
\text { Abbreviated Versions }\end{array}$ \\
\hline Kemper 3-Item Screen & $\begin{array}{l}\text { A 3-item self-report screening tool designed to assess maternal } \\
\text { depressive symptoms. Validity examined with English-speaking } \\
\text { mothers with children under } 6 \text { years of age, demonstrated } 100 \% \\
\text { sensitivity and } 88 \% \text { specificity [74]. }\end{array}$ & None & $\begin{array}{l}\text { Casey et al. } 2004 \text { [54]; Chilton et al. } \\
2013 \text { [28]; Sun et al. 2016 [30] }\end{array}$ & None \\
\hline Kessler-10 Scale & $\begin{array}{l}\text { A 10-item screen developed for the US National Health Interview } \\
\text { Survey. Designed to assess symptoms of general psychological } \\
\text { distress through items on level of nervousness, hopelessness, lack of } \\
\text { energy, depressive feelings, and worthlessness. Validity was } \\
\text { examined with adults living in Australia, aged } 18 \text { years and } \\
\text { older [79]. }\end{array}$ & None & Carter et al. 2011 [43] & None \\
\hline $\begin{array}{l}\text { Patient Health } \\
\text { Questionnaire (PHQ-9) }\end{array}$ & $\begin{array}{l}\text { A 9-item questionnaire administered in a primary care setting by } \\
\text { clinicians, designed to provide a diagnosis of major depressive } \\
\text { disorder according to DSM guidelines. Items assess depressive } \\
\text { symptoms and anhedonia experienced within the past } 2 \text { weeks. } \\
\text { Validity was assessed among patients recruited through primary care } \\
\text { offices, with } 73 \% \text { sensitivity and } 94 \% \text { specificity [80]. }\end{array}$ & PHQ-2 (2-item subset) & $\begin{array}{l}\text { Harrison et al. } 2008 \text { [60]; } \\
\text { Sidebottom et al. } 2014 \text { [33] }\end{array}$ & Trapp et al. 2015 [31] \\
\hline Pearlin's Mastery Scale & $\begin{array}{l}\text { A 7-item self-report Likert scale that measures the degree of control } \\
\text { respondents feel they have over their lives. Authors note validation } \\
\text { with individuals aged } 18 \text { to } 65 \text { years [81]. }\end{array}$ & None & $\begin{array}{l}\text { Heflin et al. } 2005 \text { [62]; Laraia et al. } \\
2006 \text { [56] }\end{array}$ & None \\
\hline $\begin{array}{l}\text { Rosenberg's } \\
\text { Self-Esteem Scale }\end{array}$ & $\begin{array}{l}\text { A 10-item self-report Likert scale that assesses level of self-esteem in } \\
\text { respondents [82]. }\end{array}$ & None & $\begin{array}{l}\text { Laraia et al. } 2006 \text { [56]; Laraia et al. } \\
2009 \text { [58] }\end{array}$ & None \\
\hline SF-36 Health Survey & $\begin{array}{l}\text { A 36-item health survey that consists of } 5 \text { physical health scales and } 5 \\
\text { mental health scales. The mental component summary score is } \\
\text { calculated from scores on } 4 \text { subscales; social functioning, role } \\
\text { emotional, vitality, and mental health scales [83]. When tested on } \\
\text { individuals } 16-74 \text { years of age, the SF-36 demonstrated good } \\
\text { construct validity in patient population. Authors noted promise in } \\
\text { use with the general population [83] }\end{array}$ & SF-12 (12-item short form) & Lent et al. 2009 [45] & Mathews et al. 2010 [34] \\
\hline $\begin{array}{l}\text { Spielberger's Trait } \\
\text { Anxiety Inventory }\end{array}$ & $\begin{array}{l}\text { The Spielberger State-Trait Anxiety Inventory is a 20-item tool } \\
\text { commonly used to measure anxiety, with higher scores indicating } \\
\text { greater levels of anxiety [72]. The American Psychological } \\
\text { Association has noted sensitivity of this inventory to predict distress } \\
\text { overtime in caregivers [72]. }\end{array}$ & & Laraia et al. 2006 [56] & None \\
\hline $\begin{array}{l}\text { World Health } \\
\text { Organization World } \\
\text { Mental Health } \\
\text { Composite } \\
\text { International } \\
\text { Diagnostic Interview } \\
\text { (CIDI) }\end{array}$ & $\begin{array}{l}\text { A comprehensive interview designed to diagnose major depressive } \\
\text { disorder, other depressive disorders, anxiety disorders, substance } \\
\text { abuse, and impulse control disorders according to the World Health } \\
\text { Organization International Classification of Disease (ICD) and DSM } \\
\text { criteria [70]. Evaluation studies suggested good test-retest and } \\
\text { interrater reliability, and its use in different settings and countries } \\
\text { was deemed acceptable [84]. }\end{array}$ & $\begin{array}{l}\text { CIDI short form (CIDI-SF), } \\
\text { also referred to as } \\
\text { screening version }\end{array}$ & None & $\begin{array}{l}\text { Corman et al. } 2016 \text { [24]; } \\
\text { Heflin et al. } 2005 \text { [62]; } \\
\text { Hernandez et al. 2014 [26]; } \\
\text { Martin et al. } 2016 \text { [17]; } \\
\text { Siefert et al. } 2001 \text { [64]; } \\
\text { Whitaker et al. } 2006 \text { [59] }\end{array}$ \\
\hline
\end{tabular}




\subsection{Overview of Findings on Food Insecurity and Mental Health}

The majority of cross-sectional analyses examining depression and food insecurity (or food insufficiency) reported some form of association deemed to be significant $[16,28,29,32,34-36,38-$ $44,54,56-60,63,64,68,69,85]$. Several longitudinal analyses likewise observed relationships between depression and food insecurity, with food insecurity increasing the risk of experiencing depressive symptoms or a depression diagnosis [44,53,62], or changes in food insecurity associated with changes in depression [62]. For example, a longitudinal analysis of data from 8693 parent-child dyads by Bronte-Tinkew et al. [53] found that mothers affected by food insecurity were more likely to report depressive symptoms compared to food-secure mothers. Some authors reported that the relationship functioned in the opposite direction, with depression leading to food insecurity [15,24-26,45], or was bidirectional [55]. For example, Garg et al., who analyzed data from the Early Childhood Longitudinal Study Birth Cohort $(n=2917)$, found that mothers who experienced depression were at greater risk of remaining food insecure over time compared to mothers without depression [25]. Food insecurity and depression were also investigated in relation to other markers of material deprivation; for example, Corman et al. [24] found that women who experienced a major depressive episode at baseline had greater odds of experiencing food insecurity and inadequate housing at follow-up.

Several articles focused on pregnant women and revealed associations between prenatal and postpartum depression and food insecurity $[33,36,42,56,60]$. Food-insecure pregnant women were at increased risk of experiencing prenatal depressive symptoms compared to their food-secure counterparts [33,36]. Although a comprehensive measure of food insecurity was not used, Birmingham et al. [42] tested depression screening methods in a cross-sectional analysis of 195 mothers of newborns and found that those who had concerns about food were 5.5 times more likely to have a positive postpartum depression screen result.

Anxiety and stress were associated with food insecurity in multiple studies [16,17,32,56,59]. Analyses of cross-sectional data from the 2007-2008 Canadian Community Health Survey (CCHS) by Tarasuk et al. $(n=77,053)$ [16] and Muldoon et al. $(n=5588)$ [32] indicated that severe food insecurity and a self-reported diagnosis of mood or anxiety disorders were associated among women. Siefert et al. [64] found an association between food insecurity and generalized anxiety disorder in a cross-sectional study of 724 US women receiving welfare, but the relationship was not significant when covariates were taken into account. In two studies, one cross-sectional $(n=606)$ [56] and one longitudinal $(n=526)$ [27], Laraia et al. found that food-insecure pregnant women had higher perceived stress compared to food-secure women, and those who had experienced any level of food insecurity during pregnancy or at three months postpartum were more likely to have high perceived stress scores at 12 months postpartum. Martin et al. [17] investigated perceived stress among Canadian adults and found that the prevalence of high levels of stress increased with lower food security status. However, Trapp et al. [31] explored food insecurity among a group of 222 low-income mothers and their children in a cross-sectional analysis and found that levels of perceived stress did not differ between food-insecure and food-secure groups.

Three recent articles explored disordered or emotional eating among women experiencing food insecurity [27,37,39]. Laraia et al. [27] and Sharpe et al. [39] found bivariate associations between food insecurity and disordered or emotional eating; however, in models adjusted for sociodemographic characteristics, Laraia et al. [27] did not observe significant associations between food insecurity and disordered eating behaviors. Dressler et al. [37] examined associations between emotional eating and depression and suggested that emotional eating may mediate associations among food insecurity, mental health, and other food-related outcomes, such as dietary intakes and weight status.

Moreover, some studies examined multiple mental and physical health conditions suggesting comorbid physical and mental health problems increased vulnerability to food insecurity $[16,34]$ and that food insecurity increased vulnerability to poor physical and mental health $[41,69]$. There was also a focus on implications for others, including children, in the household. For example, 
Bronte-Tinkew et al. [53] found that mothers living in food-insecure households reported high rates of depression, which was correlated with fair and poor health in children.

Given that the precise focus of the studies varied, a range of covariates was examined. Several studies examined various forms of social support $[15,17,35,52,60,63]$. Instrumental social support (e.g., ability to borrow money, help with childcare and transportation) was examined in a study conducted by the Detroit Centre for Oral Health Disparities. Cross-sectional analyses by Siefert et al. [63] $(n=824)$ indicated that the effect of food insufficiency on depression could be reduced with the availability of instrumental social support, while Ajrouch et al. [35] $(n=736)$ found that this protective effect was dampened when respondents experienced high levels of food insecurity-related stress. Using cross-sectional Canadian data, Martin et al. [17] $(n=100,401)$ found associations between food insecurity and feelings of community belonging; for example, the prevalences of living in severely food-insecure households were $18 \%$ and $25.6 \%$ among women reporting high and low community belonging, respectively. In a cross-sectional analysis, Wehler et al. [52] $(n=354)$ found that financial social support from a sibling reduced the odds of mothers experiencing hunger but did not reduce the odds of children in the same household experiencing hunger. Further, Hanson and Olson [15] $(n=225)$ found that parenting social support (e.g., having someone to talk to and having help in an emergency) did not reduce the odds of a household experiencing persistent vs. discontinuous food insecurity over a period of three years.

The role of childhood and adulthood adverse experiences, including abuse, was also examined. In multivariable models, Wehler et al. [52] found that sexual abuse in childhood increased the odds of adult hunger, and that this appeared to be mediated by experiences of intimate partner violence in adulthood. Sun et al. [30] examined Adverse Childhood Experiences, including abuse, neglect, and household dysfunction, and found that mothers reporting four or more adverse experiences were more likely to report food insecurity, with adjustment for demographic factors. In bivariate analyses, Harrison et al. [60] found that each of food insecurity, intimate partner violence and depressive symptoms were correlated. In multivariable models accounting for demographic factors, Melchior et al. [44] found that intimate partner violence was higher among women who had reported indications of food insecurity two years prior.

\section{Discussion}

Overall, the evidence reviewed here supports a link between food insecurity and compromised mental health among women in high-income countries. Although longitudinal data were limited, associations between food insecurity and depression appear to operate in both directions. There are multiple plausible potential pathways by which food insecurity and poor mental health may be linked. The experience of food insecurity itself is characterized by worry and anxiety about the household food supply. Toxic stress, which refers to chronic and unyielding stress without adequate social and environmental supports [13], may be one pathway through which food insecurity and mental health are intertwined. Depending on the availability and regularity of finances, periods of household food insecurity can occur repeatedly or chronically; households in the United States that were food insecure in 2016 experienced food insecurity in seven months on average [3]. Therefore, food insecurity may represent a chronic stressor that could contribute to the development of poor mental health. Conversely, a mental health condition could inhibit an individual from maintaining steady employment, thereby increasing vulnerability to food insecurity. Further, Seligman and Schillinger [86] posit that the relationship between food insecurity and poor health is cyclical; food insecurity increases the likelihood of trade-offs in food choices among those who receive low income and challenges the self-management of health conditions. Poor self-management results in higher health care and medication costs for the individual, which further contribute to financial instability and food insecurity [86]. Once an individual enters this cycle, it may be very difficult to exit, particularly in countries where there are disparities in access to health care and social supports, impacting access. Additionally, studies found an association between instances of abuse and depression and food insecurity $[26,44,52,60]$. The early 
life stress hypothesis argues that stressors experienced during key developmental periods can enhance vulnerability to mental health outcomes in adult life [87].

The majority of the available literature is cross-sectional, and further longitudinal research could shed light on the nature of the observed relationships and factors that underlie them. For example, research is needed to examine the interconnections among various markers of mental health and experiences of food insecurity across the lifespan, as well as to further examine the influence of potential mediating factors, such as social support or experiences of abuse. Many existing studies have focused on women with children, and pregnant women have also been investigated. A population of growing interest in regards to food insecurity is postsecondary students [88-91]; given that this is a life stage during which vulnerability to poor mental health is also high $[89,92,93]$, research examining the root causes of both issues and how they interact is of public health importance. At the other end of the spectrum, we also identified little research focused on older women.

Food insecurity is a complex and multidimensional phenomenon [51,94] and its measurement is also complex. Many of the reviewed studies relied upon data from the HFSSM, or an adaptation, to assess food security. The HFSSM is considered the standard in household food insecurity measurement in North America and is used widely in research and surveillance [3,4]. While this tool provides an indicator of quantitative deprivation, it focuses on economic access to food and does not capture aspects that are likely to be relevant to mental health, such as the social acceptability of food acquisition strategies [51]. For example, Hamelin et al. have described alienation that accompanies lack of access to adequate food [67], as well as the social implications [95]. Nonetheless, the HFSSM has been widely-used and, within the North American context, provides data that are comparable to those from national surveys [4,8,21]. The Household Food Insecurity Access Scale (HFIAS) [94] is a standardized tool that uses similar questions as the HFSSM and is designed to differentiate food-secure from food-insecure households across cultural contexts; this tool may be appropriate depending on the setting and populations of interest. Whenever feasible, a comprehensive tool is recommended over single or brief measures that may not accurately classify households and cannot provide insights into severity of food insecurity (thus potentially missing the opportunity to shed insights into those who are most vulnerable). Additionally, studies using mixed methods can generate unique information not yielded by a standardized measure such as the HFSSM.

There was greater variety in measures used to assess mental health compared with those used to determine household food security status, the majority involving screening for depressive symptoms, along with diagnostic measures that use more stringent criteria. Many authors noted that these tools had been tested and are widely used, but the range of tools used makes it difficult to compare across studies. As with food insecurity, abbreviated measures, such as those assessing depression and depressive symptoms, may have been limited in sensitivity and specificity compared to full measures, potentially dampening observed relationships or creating spurious effects. While the use of comprehensive measures and greater standardization of tools used to assess depression and other mental health conditions may allow for greater comparability across this body of literature and more robust inferences, it is critical for any study that the measure be well suited to the research question and the population/setting.

Furthermore, much of the existing research has focused on depression; widening this scope could enable policy and program responses that consider the potential range of mental health conditions related to inadequate food access. An emerging area of research is the link between food insecurity and disordered eating; in addition to the studies reviewed here focused on women, recent findings from a study of US adult men and women accessing a food pantry indicated a positive association between food insecurity and indicators of eating disorder pathology, such as binge eating and engaging in compensatory behaviors [96]. Additionally, few studies examined food security in relation to schizophrenia/psychosis or bipolar disorder among females.

The findings of the reviewed articles should be interpreted in light of several considerations. Most of the available research is based on US populations. While several studies were conducted among 
subpopulations such as women with children and African-American women, more research is needed to assess how food insecurity and mental health interact with other markers of vulnerability (such as single parenthood, insecure housing, drug use, experiences of violence, and immigrant/refugee status) in diverse subgroups. The majority of studies were cross-sectional, and causal inferences were not possible. Additionally, for longitudinal studies, in some cases, it was challenging to ascertain the timing of baseline and follow-up data collections. Adherence to checklists such as STROBE (Strengthening the Reporting of Observational Studies in Epidemiology) [97] could help promote transparency and accurate interpretation. Many authors noted limitations of self-reported data on mental health outcomes and food insecurity $[16,17,26,29-32,34,40,44,55,62]$. Some also noted temporal incongruence between measures of food insecurity and indicators of mental health $[25,39,41]$ that may have affected their findings. Due to the varied emphases of the studies (including assessing feasibility and other characteristics of measures), a range of covariates and potential confounders were examined; in some cases, they were used to characterize samples whereas in others, they were included in statistical models such that it is difficult to compare estimates from one study to another. Finally, explicit approaches to account for the potential conceptual overlap between food insecurity and mental health indicators, such as feelings of worry or anxiety that are conceptualized as part of the experience of food insecurity and are also markers of psychological distress, were not common.

Considerations related to the review itself also warrant highlighting. We followed methodology for a scoping study [22] and, thus, did not conduct a formal appraisal of the quality of the included evidence, nor weight the evidence. Rather, our objective was to characterize the existing literature as to identify directions for future research. Further, although we employed a systematic search strategy and careful screening, our search was broad and it is possible that some relevant articles were inadvertently excluded. Additionally, we did not consider studies that presented pooled estimates for males and females. Although our interest was in females, this does not preclude the existence of associations between food insecurity and mental health among males, as observed in some reviewed studies that include stratified analyses. Additionally, given that we relied upon published articles, we did not account for publication bias in that research not supporting relationships between food insecurity and mental health may be less likely to have been identified.

\section{Conclusions}

Overall, this review supports a link between food insecurity and poor mental health among women in high-income countries. Despite gaps, the existing evidence is sufficient to warrant policy and program interventions to address these major public health challenges in a coordinated manner. An underlying theme of the literature is the complex ways in which food insecurity and mental health are connected both to each other and to an array of other issues, such as experiences of violence, housing circumstances, and life transitions such as pregnancy. These links underscore the need for coordinated approaches that consider how policy and program interventions can best address these complex issues and their interactions. Such approaches may be informed by systems methods [98-100] that consider the interplay among factors and how interventions to address one issue may affect another issue, influencing overall health and well-being.

Strategies to address financial inadequacy, such as a guaranteed basic income, have been called for to reduce vulnerability to food insecurity $[19,101,102]$, and could play a role in ameliorating mental health conditions [103]. Additionally, food security screening has been recommended within clinical settings to enable referral to available community resources [13,104-106] (although it is imperative that practitioners have effective resources to which they can make referrals). While addressing the financial circumstances that underlie food insecurity is critical, screening for food access issues among those seeking treatment for mental health conditions could help build momentum in addressing the whole person instead of tackling issues in isolation, for example, helping health practitioners to understand, and potentially address, reasons for non-adherence to recommendations related to diet or other factors. Health and social service settings with integrated care models, in which women have access to a 
range of services that provide support during periods of food insecurity and poor mental health, may allow complex challenges to be addressed simultaneously [107]. In addition, health care providers are uniquely positioned to support individuals in accessing services such as government income-related benefits, dietary allowance benefits, or legal supports $[16,106,108]$, and alongside individuals with lived experience of vulnerability, to advocate for increased financial supports and access to mental health care.

Author Contributions: S.P.-M., S.I.K., and M.M. developed and conducted the search and screened articles. S.P.-M. and M.M. extracted data and C.L.-T., L.A., and S.I.K. verified data extraction. M.M., L.A. and S.I.K. led the manuscript development and all authors contributed critical revisions.

Funding: This research received no external funding. Open access fees were funded by a Canadian Cancer Society Research Institute Capacity Development Award (grant \#702855) held by S.I.K.

Acknowledgments: The authors are grateful to Jackie Stapleton for her guidance on the search strategy and Mona Qutub for her assistance with referencing.

Conflicts of Interest: The authors declare no conflict of interest.

\section{Appendix A}


Table A1. Key characteristics of articles ( $n=39$ from 31 studies/surveys) included in scoping review of food insecurity and mental health among women in high-income countries, by measure of food insecurity.

\begin{tabular}{|c|c|c|c|c|c|c|c|c|}
\hline Reference & $\begin{array}{l}\text { Sample (Participants } \\
\text { (Age), Setting, } \\
\text { Race/Ethnicity, Data } \\
\text { Source) }\end{array}$ & $\begin{array}{l}\text { Study Design } \\
\text { (Sample Size) }\end{array}$ & Purpose & $\begin{array}{l}\text { Food Security } \\
\text { Measure }\end{array}$ & $\begin{array}{l}\text { Mental Health } \\
\text { Measure }\end{array}$ & $\begin{array}{l}\text { Mental Health } \\
\text { States/Conditions }\end{array}$ & Covariates Considered & $\begin{array}{l}\text { Analytic Approach and Key } \\
\text { Findings }\end{array}$ \\
\hline \multicolumn{9}{|c|}{ Household Food Security Survey Module (HFSSM) } \\
\hline \multicolumn{9}{|c|}{ Longitudinal analyses } \\
\hline $\begin{array}{l}\text { Bronte-Tinkew } \\
\text { et al. } 2007 \text { [53] }\end{array}$ & $\begin{array}{l}\text { Mothers (mean age, } \\
27.5 \text { years), US, } \\
\text { race/ethnicity not } \\
\text { specified } \\
\text { Early Childhood } \\
\text { Longitudinal } \\
\text { Study-Birth Cohort } \\
\text { (ECLS-B) }\end{array}$ & $\begin{array}{l}\text { Longitudinal } \\
\text { (8693) }\end{array}$ & $\begin{array}{l}\text { Examine association } \\
\text { between food insecurity } \\
\text { and child health, and } \\
\text { examine parental } \\
\text { depression and behaviors } \\
\text { as mediators }\end{array}$ & USDA HFSSM & $\begin{array}{l}\text { CES-D 12-item } \\
\text { subset } \\
\text { Authors note } \\
\text { strong } \\
\text { psychometric } \\
\text { properties }\end{array}$ & $\begin{array}{l}\text { Symptoms of } \\
\text { maternal } \\
\text { depression }\end{array}$ & $\begin{array}{l}\text { Parent education, maternal } \\
\text { employment, maternal age } \\
\text { (at birth), family structure, } \\
\text { receipt of food subsidy, } \\
\text { child exposure to cigarette } \\
\text { smoke, number of } \\
\text { well-baby visits, household } \\
\text { poverty index ratio }\end{array}$ & $\begin{array}{l}\text { Structural equation modeling: } \\
\text { Mothers in food-insecure } \\
\text { households reported higher } \\
\text { levels of depressive symptoms } \\
(\beta=0.243, p<0.001) \text {, which } \\
\text { were associated } \\
\text { parent-reported fair or poor } \\
\text { health in children at } 24 \text { months. }\end{array}$ \\
\hline $\begin{array}{l}\text { Corman et al. } \\
2016[24]\end{array}$ & $\begin{array}{l}\text { Mothers (mean age, } 25 \\
\text { years) from } 75 \text { birth } \\
\text { hospitals in } 20 \text { US cities, } \\
\text { included White, } \\
\text { African American, } \\
\text { Hispanic, and other } \\
\text { races/ethnicities } \\
\text { Fragile Families and } \\
\text { Child Wellbeing Study }\end{array}$ & $\begin{array}{l}\text { Longitudinal } \\
\text { (2965) }\end{array}$ & $\begin{array}{l}\text { Examine association } \\
\text { between maternal } \\
\text { depression in the } \\
\text { postpartum year, housing } \\
\text { conditions, and food } \\
\text { insecurity }\end{array}$ & USDA HFSSM & $\begin{array}{l}\text { CIDI short form } \\
\text { Authors note } \\
\text { that the } \\
\text { measure has } \\
\text { been validated }\end{array}$ & $\begin{array}{l}\text { Clinical diagnosis } \\
\text { of a MDE (defined } \\
\text { as } 3+\text { symptoms } \\
\text { of dysphoria or } \\
\text { anhedonia for } \\
\text { most of the day } \\
\text { for a period of at } \\
\text { least } 2 \text { weeks) } \\
\text { during the } \\
\text { postpartum year } \\
\text { (assessed at } 1 \\
\text { year) }\end{array}$ & $\begin{array}{l}\text { Maternal, paternal, and } \\
\text { prenatal housing } \\
\text { characteristics (measured } \\
\text { at baseline), maternal } \\
\text { grandparents' mental } \\
\text { illness and child } \\
\text { characteristics }\end{array}$ & $\begin{array}{l}\text { Multivariable analysis: } \\
\text { Compared to women who did } \\
\text { not report depression, mothers } \\
\text { who reported depression were } \\
\text { more likely to experience } \\
\text { inadequate housing at 2-3 } \\
\text { years due to lack of heat (aOR } \\
1.57,95 \% \text { CI 1.11-2.22) and } \\
\text { energy insecurity (aOR 1.69, } \\
95 \% \text { CI 1.24-2.30). Depression } \\
\text { was associated with } \\
\text { combinations of hardships, } \\
\text { including inadequate housing, } \\
\text { housing instability, and food } \\
\text { insecurity (aOR 3.85, 95\% CI } \\
\text { 1.34-11.11). }\end{array}$ \\
\hline $\begin{array}{l}\text { Garg et al. } \\
2015 \text { [25] }\end{array}$ & 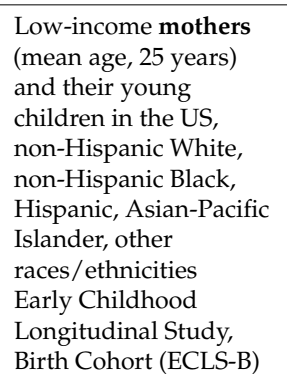 & $\begin{array}{l}\text { Longitudinal } \\
\text { (2917) }\end{array}$ & $\begin{array}{l}\text { To determine impact of } \\
\text { maternal depression on } \\
\text { future household food } \\
\text { insecurity in low-income } \\
\text { households with young } \\
\text { children. }\end{array}$ & USDA HFSSM & $\begin{array}{l}\text { CES-D } 12 \text { item } \\
\text { Authors note } \\
\text { that the short } \\
\text { form has been } \\
\text { previously } \\
\text { validated. }\end{array}$ & $\begin{array}{l}\text { Depressive } \\
\text { symptoms }\end{array}$ & $\begin{array}{l}\text { Maternal and household } \\
\text { characteristics including } \\
\text { race/ethnicity, age, marital } \\
\text { status, employment, } \\
\text { education, mothers' } \\
\text { foreign-born status, } \\
\text { household income, and } \\
\text { maternal self-reported } \\
\text { health status. }\end{array}$ & $\begin{array}{l}\text { Multivariable analyses: } \\
\text { Maternal depression at } \\
\text { baseline ( } 9 \text { months) was } \\
\text { associated with food insecurity } \\
\text { at follow-up ( } 24 \text { months) (aOR } \\
1.50,95 \% \text { CI } 1.06-2.12 \text { ). } \\
\text { Mothers who reported } \\
\text { depressive symptoms and } \\
\text { received WIC at baseline were } \\
\text { more likely (aOR } 1.59,95 \% \text { CI } \\
1.15-2.21 \text { ) to experience food } \\
\text { insecurity at follow-up. }\end{array}$ \\
\hline
\end{tabular}


Table A1. Cont.

\begin{tabular}{|c|c|c|c|c|c|c|c|c|}
\hline Reference & $\begin{array}{l}\text { Sample (Participants } \\
\text { (Age), Setting, } \\
\text { Race/Ethnicity, Data } \\
\text { Source) }\end{array}$ & $\begin{array}{l}\text { Study Design } \\
\text { (Sample Size) }\end{array}$ & Purpose & $\begin{array}{l}\text { Food Security } \\
\text { Measure }\end{array}$ & $\begin{array}{l}\text { Mental Health } \\
\text { Measure }\end{array}$ & $\begin{array}{c}\text { Mental Health } \\
\text { States/Conditions }\end{array}$ & Covariates Considered & $\begin{array}{l}\text { Analytic Approach and Key } \\
\text { Findings }\end{array}$ \\
\hline $\begin{array}{l}\text { Hanson et al. } \\
2012 \text { [15] }\end{array}$ & $\begin{array}{l}\text { Low income, rural } \\
\text { mothers (mean age, } 30 \\
\text { years) in US, White and } \\
\text { non-White } \\
\text { races/ethnicities } \\
\text { Rural Low-Income } \\
\text { Families: Monitoring } \\
\text { Their Well-being and } \\
\text { Functioning in the } \\
\text { Context of Welfare } \\
\text { Reform }\end{array}$ & $\begin{array}{l}\text { Longitudinal } \\
(225)\end{array}$ & $\begin{array}{l}\text { Examine food insecurity } \\
\text { and various risk factors, } \\
\text { including human capital, } \\
\text { social support, and } \\
\text { financial situation, } \\
\text { among rural low-income } \\
\text { families with children. }\end{array}$ & USDA HFSSM & CES-D 20-item & $\begin{array}{l}\text { Depressive } \\
\text { symptoms }\end{array}$ & $\begin{array}{l}\text { Education, } 3 \text { or more } \\
\text { chronic health conditions, } \\
\text { food and financial skills, } \\
\text { high support for parenting, } \\
\text { home ownership at } \\
\text { baseline, employment, } \\
\text { housing assistance, } \\
\text { participation in SNAP } \\
\text { assistance, health insurance }\end{array}$ & $\begin{array}{l}\text { Multivariable analyses: } \\
\text { Compared to women having } \\
\text { no years at risk for depression, } \\
\text { women classified as at risk for } \\
\text { depression for } 2 \text { consecutive } \\
\text { years had } 4.28 \text { times greater } \\
\text { odds of experiencing persistent } \\
\text { versus no food insecurity } \\
(p<0.01) \text {, and } 3.65 \text { times } \\
\text { greater odds to experience } \\
\text { persistent versus } \\
\text { discontinuous food insecurity } \\
(p<0.05) \text {. }\end{array}$ \\
\hline $\begin{array}{l}\text { Hernandez et al. } \\
2014 \text { [26] }\end{array}$ & $\begin{array}{l}\text { Low-income, urban, } \\
\text { unmarried mothers } \\
\text { (mean age, } 28 \text { years) of } \\
\text { newborn children } \\
\text { recruited from } 75 \text { birth } \\
\text { hospitals in } 20 \text { US cities, } \\
\text { White, African } \\
\text { American, Hispanic, } \\
\text { and other } \\
\text { races/ethnicities } \\
\text { Fragile Families and } \\
\text { Child Well-being Study }\end{array}$ & $\begin{array}{l}\text { Longitudinal } \\
(1690)\end{array}$ & $\begin{array}{l}\text { Examine association } \\
\text { between intimate partner } \\
\text { violence, depression, and } \\
\text { household food } \\
\text { insecurity }\end{array}$ & USDA HFSSM & CIDI short form & $\begin{array}{l}\text { Clinical diagnosis } \\
\text { of depression; } \\
\text { depressive } \\
\text { symptoms }\end{array}$ & $\begin{array}{l}\text { Mothers' age, } \\
\text { race/ethnicity, education, } \\
\text { employment, relationship } \\
\text { status, household income, } \\
\text { number of children, } \\
\text { baseline food security }\end{array}$ & $\begin{array}{l}\text { Multivariable analyses: } \\
\text { Mothers reporting depression } \\
\text { were twice as likely to be } \\
\text { food-insecure two years later } \\
\text { compared to mothers who did } \\
\text { not report depression (aOR } \\
2.03,95 \% \text { CI } 1.45-2.84) \text {. The } \\
\text { relationship between intimate } \\
\text { partner violence and food } \\
\text { insecurity among women was } \\
\text { mediated by depression } \\
(\mathrm{z}=2.89, p<0.01) .\end{array}$ \\
\hline $\begin{array}{l}\text { Lent et al. } \\
2009 \text { [45] }\end{array}$ & $\begin{array}{l}\text { Rural, low-income } \\
\text { mothers (18+ years), } \\
\text { recruited through local } \\
\text { educators, WIC and } \\
\text { Even Start programs in } \\
\text { New York, US, majority } \\
\text { White. } \\
\text { Rural Families Speak: } \\
\text { Tracking the Well-Being } \\
\text { and Functioning of } \\
\text { Rural Families in the } \\
\text { Context of Welfare } \\
\text { Policies Study }\end{array}$ & $\begin{array}{l}\text { Longitudinal } \\
\text { (mixed } \\
\text { methods) (29) }\end{array}$ & $\begin{array}{l}\text { Examine the } \\
\text { temporal/causal } \\
\text { relationship and potential } \\
\text { mechanisms between } \\
\text { mental health conditions } \\
\text { such as depression and } \\
\text { household food } \\
\text { insecurity }\end{array}$ & USDA HFSSM & $\begin{array}{l}\text { CES-D 20-item, } \\
\text { SF-36 Health } \\
\text { Survey (mental } \\
\text { health scales: } \\
\text { Vitality, Social } \\
\text { Functioning, } \\
\text { Role Emotional, } \\
\text { Mental Health) }\end{array}$ & $\begin{array}{l}\text { Depressive } \\
\text { symptoms }\end{array}$ & Not applicable & $\begin{array}{l}\text { Unadjusted analyses: High } \\
\text { levels of depressive symptoms } \\
\text { (according to the CES-D) at } \\
\text { wave } 2 \text { were correlated with } \\
\text { remaining food-insecure at } \\
\text { wave } 3 \text { ( } p=0.009) \text {; reverse } \\
\text { relationship not significant. } \\
\text { Unhealthy scores on the } \\
\text { mental health scores at wave } 2 \\
\text { were also associated with } \\
\text { remaining food-insecure at } \\
\text { wave } 3 \text { ( } p=0.01 \text { ). Qualitative } \\
\text { analyses suggest that poor } \\
\text { mental health contributes to } \\
\text { persistence of food insecurity } \\
\text { by limiting employment. }\end{array}$ \\
\hline
\end{tabular}


Table A1. Cont.

\begin{tabular}{|c|c|c|c|c|c|c|c|c|}
\hline Reference & $\begin{array}{l}\text { Sample (Participants } \\
\text { (Age), Setting, } \\
\text { Race/Ethnicity, Data } \\
\text { Source) }\end{array}$ & $\begin{array}{l}\text { Study Design } \\
\text { (Sample Size) }\end{array}$ & Purpose & $\begin{array}{l}\text { Food Security } \\
\text { Measure }\end{array}$ & $\begin{array}{l}\text { Mental Health } \\
\text { Measure }\end{array}$ & $\begin{array}{c}\text { Mental Health } \\
\text { States/Conditions }\end{array}$ & Covariates Considered & $\begin{array}{l}\text { Analytic Approach and } \\
\text { Key Findings }\end{array}$ \\
\hline $\begin{array}{l}\text { Huddleston-Casas } \\
\text { et al. } 2009 \text { [55] }\end{array}$ & $\begin{array}{l}\text { Rural mothers (mean } \\
\text { age, } 30 \text { years) recruited } \\
\text { from programs serving } \\
\text { low-income } \\
\text { populations in } 17 \text { US } \\
\text { states, included White, } \\
\text { African American, } \\
\text { Latina, and other } \\
\text { races/ethnicities } \\
\text { NC-223, Rural Families } \\
\text { Speak Study }\end{array}$ & $\begin{array}{l}\text { Longitudinal } \\
\text { (413) }\end{array}$ & $\begin{array}{l}\text { Examine direction of the } \\
\text { relationship between } \\
\text { household food } \\
\text { insecurity and depression } \\
\text { over three annual waves } \\
\text { of data }\end{array}$ & USDA HFSSM & $\begin{array}{l}\text { CES-D 20-item } \\
\text { Authors note } \\
\text { that reliability in } \\
\text { this sample } \\
\text { matched that } \\
\text { documented for } \\
\text { the general } \\
\text { population }\end{array}$ & $\begin{array}{l}\text { Depressive } \\
\text { symptoms }\end{array}$ & $\begin{array}{l}\text { Age, ethnicity, household } \\
\text { income, marital status, } \\
\text { education }\end{array}$ & $\begin{array}{l}\text { Structural equation } \\
\text { modeling (using data for } \\
413 \text { women, with } \\
\text { sensitivity analysis with } \\
184 \text { women who had } \\
\text { depression data for three } \\
\text { waves): A bidirectional } \\
\text { relationship between food } \\
\text { insecurity and depression } \\
\left(\mathrm{X}^{2} / \mathrm{df}=1.835, \mathrm{RMSEA}=\right. \\
0.068, \mathrm{CFI}=0.989 \text { ) was } \\
\text { observed. }\end{array}$ \\
\hline $\begin{array}{l}\text { Laraia et al. } \\
2015[27]\end{array}$ & $\begin{array}{l}\text { Pregnant women (16+ } \\
\text { years), US, included } \\
\text { White, Black, other } \\
\text { races/ethnicities } \\
\text { Pregnancy, Infection, } \\
\text { and Nutrition (PIN) } \\
\text { Postpartum study, } \\
\text { recruited from } \\
\text { University of North } \\
\text { Carolina Hospitals and } \\
\text { private clinics }\end{array}$ & $\begin{array}{l}\text { Longitudinal } \\
\text { (526) }\end{array}$ & $\begin{array}{l}\text { To examine relationship } \\
\text { between food insecurity } \\
\text { and perceived stress, } \\
\text { disordered eating, dietary } \\
\text { intake, and postpartum } \\
\text { weight status }\end{array}$ & $\begin{array}{l}\text { USDA HFSSM, } \\
18 \text { items } \\
\text { (between } 27 \text { and } \\
30 \text { weeks' } \\
\text { gestation) and } \\
6 \text {-item short } \\
\text { form ( } 12 \text { months } \\
\text { postpartum) }\end{array}$ & $\begin{array}{l}\text { Cohen's } \\
\text { Perceived Stress } \\
\text { Scale (PSS) } \\
\text { 10-item, Eating } \\
\text { Attitude Test } \\
\text { (EAT) } 26 \text { item } \\
\text { Authors note } \\
\text { that Cohen's } \\
\text { Perceived Stress } \\
\text { has been } \\
\text { validated in } \\
\text { pregnant } \\
\text { women }\end{array}$ & $\begin{array}{l}\text { Perceived stress, } \\
\text { disordered eating }\end{array}$ & $\begin{array}{l}\text { Maternal race, age, marital } \\
\text { status, education, parity, } \\
\text { physical activity, smoking } \\
\text { during pregnancy and } \\
\text { postpartum, breastfeeding } \\
\text { postpartum, poverty level }\end{array}$ & $\begin{array}{l}\text { Multivariable analyses: } \\
\text { Women living in } \\
\text { food-insecure households } \\
\text { during pregnancy had } \\
\text { higher levels of perceived } \\
\text { stress ( } \beta=3.36,95 \% \text { CI } \\
0.79-5.92) \text { and higher } \\
\text { scores for disordered eating } \\
\text { ( } \beta=1.95,95 \% \text { CI } 0.25-4.16) \\
\text { at } 3 \text { months postpartum } \\
\text { and higher levels of } \\
\text { perceived stress ( } \beta=3.67 \text {, } \\
95 \% \text { CI } 0.94-6.41) \text { at } 12 \\
\text { months postpartum } \\
\text { compared to those living in } \\
\text { food-secure households } \\
\text { during pregnancy. Women } \\
\text { who experienced any level } \\
\text { of household food } \\
\text { insecurity during the } \\
\text { postpartum period had } \\
\text { higher perceived stress } \\
\text { ( } \beta=6.12,95 \% \text { CI } 3.86-8.38) \text {, } \\
\text { and higher scores for } \\
\text { disordered eating ( } \beta=1.79 \text {, } \\
\text { 95\% CI 0.03-3.62) } \\
\text { compared to women in } \\
\text { food-secure households. }\end{array}$ \\
\hline
\end{tabular}


Table A1. Cont.

\begin{tabular}{|c|c|c|c|c|c|c|c|c|}
\hline Reference & $\begin{array}{l}\text { Sample (Participants } \\
\text { (Age), Setting, } \\
\text { Race/Ethnicity, Data } \\
\text { Source) }\end{array}$ & $\begin{array}{l}\text { Study Design } \\
\text { (Sample Size) }\end{array}$ & Purpose & $\begin{array}{l}\text { Food Security } \\
\text { Measure }\end{array}$ & $\begin{array}{l}\text { Mental Health } \\
\text { Measure }\end{array}$ & $\begin{array}{c}\text { Mental Health } \\
\text { States/Conditions }\end{array}$ & Covariates Considered & $\begin{array}{c}\text { Analytic Approach and Key } \\
\text { Findings }\end{array}$ \\
\hline \multicolumn{9}{|c|}{ Cross-sectional analyses } \\
\hline $\begin{array}{l}\text { Casey et al. } \\
2004[54]\end{array}$ & $\begin{array}{l}\text { Female caregivers (age } \\
\text { not specified), US, } \\
\text { women of African } \\
\text { American, White, and } \\
\text { Hispanic race/ethnicity } \\
\text { Children's Sentinel } \\
\text { Nutrition Assessment } \\
\text { Program (C-SNAP), } \\
\text { recruited from medical } \\
\text { centers in several large } \\
\text { US cities }\end{array}$ & $\begin{array}{l}\text { Cross-sectional } \\
(5306)\end{array}$ & $\begin{array}{l}\text { Examine nature of the } \\
\text { relationship between } \\
\text { depression, food } \\
\text { insecurity, and loss of } \\
\text { social assistance and its } \\
\text { impact on child health }\end{array}$ & USDA HFSSM & $\begin{array}{l}\text { Kemper 3-item } \\
\text { screen } \\
\text { Authors note } \\
\text { sensitivity of } \\
100 \% \text {, specificity } \\
\text { of } 88 \% \text {, and } \\
\text { positive } \\
\text { predictive value } \\
\text { of } 66 \% \\
\text { compared to an } \\
\text { 8-item screening } \\
\text { instrument }\end{array}$ & $\begin{array}{l}\text { Maternal } \\
\text { depressive } \\
\text { symptoms }\end{array}$ & $\begin{array}{l}\text { Study site location, race, } \\
\text { insurance type, education, } \\
\text { and low birth weight }\end{array}$ & $\begin{array}{l}\text { Multivariable analysis: } \\
\text { Mothers experiencing food } \\
\text { insecurity had greater odds of } \\
\text { positive depression screen } \\
\text { compared to those from food } \\
\text { secure households (aOR 2.69, } \\
95 \% \text { CI } 2.33-3.11 \text { ). Mothers } \\
\text { experiencing a decrease or } \\
\text { sanction in food stamp status } \\
\text { had increased odds of } \\
\text { reporting a positive depression } \\
\text { screen, compared to those with } \\
\text { no decrease in food stamp } \\
\text { status (aOR } 1.26,95 \% \mathrm{CI} \\
0.97-1.65 \text { and aOR } 1.5695 \% \mathrm{Cl} \\
1.06-2.30 \text {, respectively). }\end{array}$ \\
\hline $\begin{array}{l}\text { Chilton et al. } \\
2013[28]\end{array}$ & $\begin{array}{l}\text { Mothers (mean age, } \\
26.7 \text { years) in } \\
\text { Philadelphia, US, } \\
\text { African American, } \\
\text { White, Hispanic } \\
\text { races/ethnicities } \\
\text { Recruited from public } \\
\text { assistance programs } \\
\text { through the Children's } \\
\text { Health Watch study }\end{array}$ & $\begin{array}{l}\text { Cross-sectional } \\
\text { (mixed } \\
\text { methods) (44) }\end{array}$ & $\begin{array}{l}\text { Explore aspects of } \\
\text { exposure to violence } \\
\text { related to food insecurity } \\
\text { among lone mother } \\
\text { households. }\end{array}$ & USDA HFSSM & $\begin{array}{l}\text { Kemper 3-item } \\
\text { screen }\end{array}$ & $\begin{array}{l}\text { Maternal } \\
\text { depressive } \\
\text { symptoms }\end{array}$ & Not applicable & $\begin{array}{l}\text { Descriptive estimates: A higher } \\
\text { proportion of mothers living } \\
\text { with very low food security } \\
\text { reported depressive symptoms } \\
(71 \%) \text { compared to those with } \\
\text { low food security }(53 \%) \text { and } \\
\text { food-secure }(17 \%) \text { mothers. } \\
\text { Women living with very low } \\
\text { food security ( } 53 \% \text { ) were more } \\
\text { likely to have experienced } \\
\text { life-changing violence in } \\
\text { childhood compared to those } \\
\text { with low food security }(33 \%) \\
\text { and food secure }(33 \%) \text { mothers }\end{array}$ \\
\hline $\begin{array}{l}\text { McCurdy et al. } \\
2015 \text { [29] }\end{array}$ & $\begin{array}{l}\text { Low-income mothers } \\
\text { (mean age, } 30.1 \text { years) } \\
\text { and children recruited } \\
\text { from } 7 \text { preschools in } \\
\text { low-income urban } \\
\text { neighborhoods in the } \\
\text { US, included Hispanic } \\
\text { and non-Hispanic } \\
\text { races/ethnicities }\end{array}$ & $\begin{array}{l}\text { Cross-sectional } \\
(166)\end{array}$ & $\begin{array}{l}\text { To determine correlates } \\
\text { of weight, including food } \\
\text { security, among } \\
\text { low-income, ethnically } \\
\text { diverse mothers and } \\
\text { examine role of mental } \\
\text { health }\end{array}$ & USDA HFSSM & $\begin{array}{l}\text { CES-D 20-item } \\
\text { Authors note } \\
\text { high internal } \\
\text { consistency for } \\
\text { the measure and } \\
\text { note acceptable } \\
\text { internal } \\
\text { reliability in this } \\
\text { sample }\end{array}$ & $\begin{array}{l}\text { Depressive } \\
\text { symptoms }\end{array}$ & Not applicable & $\begin{array}{l}\text { Bivariate analyses: Mothers } \\
\text { living in food-insecure } \\
\text { households had more } \\
\text { depressive symptoms } \\
\text { compared to food-secure } \\
\text { mothers }(\mathrm{t}=2.26, p<0.02) \text {. }\end{array}$ \\
\hline
\end{tabular}


Table A1. Cont.

\begin{tabular}{|c|c|c|c|c|c|c|c|c|}
\hline Reference & $\begin{array}{l}\text { Sample (Participants } \\
\text { (Age), Setting, } \\
\text { Race/Ethnicity, Data } \\
\text { Source) }\end{array}$ & $\begin{array}{l}\text { Study Design } \\
\text { (Sample Size) }\end{array}$ & Purpose & $\begin{array}{l}\text { Food Security } \\
\text { Measure }\end{array}$ & $\begin{array}{l}\text { Mental Health } \\
\text { Measure }\end{array}$ & $\begin{array}{l}\text { Mental Health } \\
\text { States/Conditions }\end{array}$ & Covariates Considered & $\begin{array}{c}\text { Analytic Approach and Key } \\
\text { Findings }\end{array}$ \\
\hline $\begin{array}{l}\text { Sun et al. } \\
2016[30]\end{array}$ & $\begin{array}{l}\text { Mothers (mean age, } \\
24 \text { years) of young } \\
\text { children } \\
\text { (aged < } 4 \text { years), US, } \\
\text { non-Hispanic White, } \\
\text { non-Hispanic Black, } \\
\text { Hispanic, other } \\
\text { races/ethnicities, } \\
\text { recruited from } \\
\text { Philadelphia hospitals. }\end{array}$ & $\begin{array}{l}\text { Cross-sectional } \\
\text { (1255) }\end{array}$ & $\begin{array}{l}\text { To examine association } \\
\text { between adverse } \\
\text { childhood experiences } \\
\text { among mothers and } \\
\text { household and child food } \\
\text { insecurity determine } \\
\text { associations with } \\
\text { depressive symptoms }\end{array}$ & USDA HFSSM & $\begin{array}{l}\text { Kemper 3-Item } \\
\text { Screen, ACEs } \\
\text { scale for } \\
\text { Adverse } \\
\text { Childhood } \\
\text { Experiences } \\
\text { Authors note } \\
\text { that the Kemper } \\
\text { 3-item is } \\
\text { validated as a } \\
\text { proxy for a } \\
\text { longer screener } \\
\text { with 100\% } \\
\text { sensitivity, 88\% } \\
\text { specificity, and } \\
66 \% \text { positive } \\
\text { predictive value, } \\
\text { and ACEs scale } \\
\text { has been } \\
\text { validated and } \\
\text { shown to have } \\
\text { good test-retest } \\
\text { reliability. }\end{array}$ & $\begin{array}{l}\text { Depressive } \\
\text { symptoms, } \\
\text { adverse } \\
\text { childhood } \\
\text { experiences, such } \\
\text { as abuse, neglect, } \\
\text { and household } \\
\text { dysfunction }\end{array}$ & $\begin{array}{l}\text { Caregiver's age and } \\
\text { self-rated health, } \\
\text { caregiver's participation in } \\
\text { nutrition programs, } \\
\text { race/ethnicity, marital } \\
\text { status, employment, } \\
\text { education, and child's } \\
\text { health insurance, }\end{array}$ & $\begin{array}{l}\text { Depressive symptoms were } \\
\text { reported among } 18.4 \% \text { of } \\
\text { women in food-secure } \\
\text { households, } 48.6 \% \text { of those in } \\
\text { households with low food } \\
\text { security, and } 54.4 \% \text { of those in } \\
\text { households with very low food } \\
\text { security ( } p<0.01 \text { ). } \\
\text { Multivariable analyses: } \\
\text { Mothers who reported } \\
\text { depressive symptoms and } 4+ \\
\text { adverse childhood experiences } \\
\text { were } 2.3 \text { times ( } 95 \% \text { CI } 1.0-5.3 \text { ) } \\
\text { as likely to report low food } \\
\text { security, } 6.6 \text { times (95\% CI } \\
2.1-20.5 \text { ) as likely to report } \\
\text { indications of very low food } \\
\text { security compared to those } \\
\text { reporting depressive } \\
\text { symptoms but no adverse } \\
\text { childhood experiences. In } \\
\text { addition, mothers who } \\
\text { reported depressive symptoms } \\
\text { and } 4+\text { adverse childhood } \\
\text { experiences were } 17.6 \text { times } \\
\text { (95\% CI } 7.3-42.6 \text { ) as likely to } \\
\text { report child food insecurity } \\
\text { compared to those who } \\
\text { reported no depressive } \\
\text { symptoms and no adverse } \\
\text { childhood experiences. }\end{array}$ \\
\hline $\begin{array}{l}\text { Trapp et al. } \\
2015 \text { [31] }\end{array}$ & $\begin{array}{l}\text { Low-income children } \\
\text { ( } 2-4 \text { years) and } \\
\text { mothers ( } 18+\text { years), } \\
\text { US, Hispanic, } \\
\text { African-American } \\
\text { races/ethnicities } \\
\text { Steps to Growing Up } \\
\text { Health study, primary } \\
\text { care-based intervention }\end{array}$ & $\begin{array}{l}\text { Cross-sectional } \\
\text { (222) }\end{array}$ & $\begin{array}{l}\text { Examine relationship } \\
\text { between food security, } \\
\text { diet, and weight status } \\
\text { among urban preschool } \\
\text { children, and examine } \\
\text { whether maternal } \\
\text { depression and stress acts } \\
\text { as a mediator }\end{array}$ & USDA HFSSM & $\begin{array}{l}\text { PHQ-2, Cohen's } \\
\text { Perceived Stress } \\
\text { Scale 4-item } \\
\text { subset (PSS-4) } \\
\text { Authors note } \\
\text { that the PHQ-2 } \\
\text { has good } \\
\text { validity, and } \\
\text { identified the } \\
\text { sensitivity and } \\
\text { specificity of the } \\
\text { cutoff used for } \\
\text { risk for major } \\
\text { depression }\end{array}$ & $\begin{array}{l}\text { Depressive } \\
\text { symptoms and } \\
\text { perceived stress }\end{array}$ & $\begin{array}{l}\text { Household size, primary } \\
\text { home language, marital } \\
\text { status, employment, } \\
\text { household income }\end{array}$ & $\begin{array}{l}\text { Bivariate analyses: Mothers } \\
\text { living in food-insecure } \\
\text { households were more likely to } \\
\text { report depressive symptoms } \\
\text { compared to food-secure } \\
\text { mothers }(27 \% \text { vs. } 9 \% \text {; } \\
p<0.001), \text { but perceived stress } \\
\text { scores were not different } \\
\text { between food-insecure and } \\
\text { food-secure mothers }(p=0.5) \text {. }\end{array}$ \\
\hline
\end{tabular}


Table A1. Cont.

\begin{tabular}{|c|c|c|c|c|c|c|c|c|}
\hline Reference & $\begin{array}{l}\text { Sample (Participants } \\
\text { (Age), Setting, } \\
\text { Race/Ethnicity, Data } \\
\text { Source) }\end{array}$ & $\begin{array}{l}\text { Study Design } \\
\text { (Sample Size) }\end{array}$ & Purpose & $\begin{array}{c}\text { Food Security } \\
\text { Measure }\end{array}$ & $\begin{array}{l}\text { Mental Health } \\
\text { Measure }\end{array}$ & $\begin{array}{l}\text { Mental Health } \\
\text { States/Conditions }\end{array}$ & Covariates Considered & $\begin{array}{l}\text { Analytic Approach and Key } \\
\text { Findings }\end{array}$ \\
\hline $\begin{array}{l}\text { Laraia et al. } \\
2006[56]\end{array}$ & $\begin{array}{l}\text { Low-income pregnant } \\
\text { women (mean age, } \\
29 \text { years), US, included } \\
\text { African American, } \\
\text { White, and other } \\
\text { races/ethnicities } \\
\text { Pregnancy, Infection, } \\
\text { and Nutrition (PIN) } \\
\text { cohort study, recruited } \\
\text { from University of } \\
\text { North Carolina } \\
\text { Hospitals and private } \\
\text { clinics }\end{array}$ & $\begin{array}{l}\text { Cross-sectional } \\
(606)\end{array}$ & $\begin{array}{l}\text { Examine prevalence } \\
\text { and determinants of } \\
\text { food insecurity among } \\
\text { pregnant women from } \\
\text { medium- and } \\
\text { low-income women }\end{array}$ & USDA HFSSM & $\begin{array}{l}\text { Cohen's } \\
\text { Perceived Stress } \\
\text { Scale 14-item, } \\
\text { Spielberger's Trait } \\
\text { Anxiety Inventory } \\
\text { 20-item, CES-D } \\
\text { 20-item, } \\
\text { Rosenberg's Self } \\
\text { Esteem Scale } \\
\text { 10-item, Pearlin's } \\
\text { Mastery Scale } \\
\text { 7-item, } \\
\text { Levenson's IPC } \\
\text { Locus of Control } \\
\text { 24-item } \\
\text { Authors note } \\
\text { stability and } \\
\text { internal } \\
\text { consistency of } \\
\text { measures }\end{array}$ & $\begin{array}{l}\text { Perceived stress, } \\
\text { anxiety, } \\
\text { depressive } \\
\text { symptoms, } \\
\text { self-esteem, } \\
\text { mastery, locus of } \\
\text { control }\end{array}$ & $\begin{array}{l}\text { Mother's age, number of } \\
\text { children, household } \\
\text { income, education, race, } \\
\text { marital status }\end{array}$ & $\begin{array}{l}\text { Multivariable analyses: } \\
\text { Perceived stress (aOR } 2.24,95 \% \\
\text { CI 1.63-3.08), trait anxiety } \\
\text { (aOR 2.14, } 95 \% \text { CI 1.55-2.96), } \\
\text { depressive symptoms (aOR } \\
1.87,95 \% \text { CI 1.40-2.51), and } \\
\text { feeling that ones' destiny is up } \\
\text { to chance (aOR } 1.67,95 \% \text { CI } \\
1.20-2.32 \text { ) were positively } \\
\text { associated with household } \\
\text { food insecurity. Women living } \\
\text { in food-insecure households } \\
\text { were less likely to report } \\
\text { feelings of mastery over their } \\
\text { lives (aOR } 0.49,95 \% \text { CI } \\
0.35-0.68 \text { ) and high self-esteem } \\
\text { (aOR } 0.52,95 \% \text { CI } 0.38-0.69 \text { ). }\end{array}$ \\
\hline $\begin{array}{l}\text { Muldoon et al. } \\
2013 \text { [32] }\end{array}$ & $\begin{array}{l}\text { Adults (18-64 years), } \\
\text { Canada } \\
\text { 2007-2008 Canadian } \\
\text { Community Health } \\
\text { Survey }\end{array}$ & $\begin{array}{l}\text { Cross-sectional } \\
\text { (sample subset } \\
\text { of } 5588 \\
\text { reporting } \\
\text { indications of } \\
\text { food insecurity } \\
\text { in the past year) }\end{array}$ & $\begin{array}{l}\text { Examine rates of } \\
\text { mental illness among } \\
\text { Canadian adults who } \\
\text { lived in food-insecure } \\
\text { households with and } \\
\text { without hunger }\end{array}$ & $\begin{array}{l}\text { USDA HFSSM } \\
\text { (Health Canada } \\
\text { coding) }\end{array}$ & $\begin{array}{l}\text { Self-reported } \\
\text { diagnosis of } \\
\text { chronic health } \\
\text { conditions } \\
\text { diagnosed by a } \\
\text { health } \\
\text { professional }\end{array}$ & $\begin{array}{l}\text { Clinical diagnoses } \\
\text { of mood or } \\
\text { anxiety disorders }\end{array}$ & $\begin{array}{l}\text { Education, age, single } \\
\text { parent household status, } \\
\text { immigrant status }\end{array}$ & $\begin{array}{l}\text { Multivariable analyses: } \\
\text { Females experiencing food } \\
\text { insecurity with hunger had } \\
\text { greater odds (aOR 1.89, } 95 \% \text { CI } \\
\text { 1.62-2.20) of reporting a } \\
\text { depression diagnosis } \\
\text { compared to women who did } \\
\text { not report food insecurity with } \\
\text { hunger. }\end{array}$ \\
\hline $\begin{array}{l}\text { Tarasuk et al. } \\
2013[16]\end{array}$ & $\begin{array}{l}\text { Adults (18-64 years), } \\
\text { Canada } \\
\text { 2007-2008 Canadian } \\
\text { Community Health } \\
\text { Survey }\end{array}$ & $\begin{array}{l}\text { Cross-sectional } \\
(77,053)\end{array}$ & $\begin{array}{l}\text { Examine whether } \\
\text { chronic physical and } \\
\text { mental conditions } \\
\text { health conditions are } \\
\text { associated with } \\
\text { household food } \\
\text { insecurity }\end{array}$ & $\begin{array}{l}\text { USDA HFSSM } \\
\text { (Health Canada } \\
\text { coding) }\end{array}$ & $\begin{array}{l}\text { Self-reported } \\
\text { presence of } \\
\text { chronic health } \\
\text { conditions } \\
\text { diagnosed by a } \\
\text { health } \\
\text { professional }\end{array}$ & $\begin{array}{l}\text { Clinical diagnoses } \\
\text { of mood or } \\
\text { anxiety disorders }\end{array}$ & $\begin{array}{l}\text { Age, sex, province, } \\
\text { education, household type, } \\
\text { median household income, } \\
\text { main source of household } \\
\text { income, and home } \\
\text { ownership }\end{array}$ & $\begin{array}{l}\text { Multivariable analysis: } \\
\text { Self-reported diagnoses of } 3 \text { or } \\
\text { more chronic physical and } \\
\text { mental health conditions raised } \\
\text { the odds of a woman } \\
\text { experiencing severe food } \\
\text { insecurity (aOR } 2.15,95 \% \mathrm{CI} \\
1.50-3.10 \text { ) compared to fewer } \\
\text { or no chronic conditions } \\
\text { Among women in food-secure } \\
\text { households, } 11.6 \% \text { reported } \\
\text { mood or anxiety disorders; } \\
\text { among those in marginally } \\
\text { food-secure, moderately } \\
\text { food-insecure, and severely } \\
\text { food-insecure households, the } \\
\text { prevalences were } 20.3 \%, 26.8 \% \text {, } \\
\text { and } 47.1 \% \text {, respectively. }\end{array}$ \\
\hline
\end{tabular}


Table A1. Cont.

\begin{tabular}{|c|c|c|c|c|c|c|c|c|}
\hline Reference & $\begin{array}{c}\text { Sample (Participants } \\
\text { (Age), Setting, } \\
\text { Race/Ethnicity, Data } \\
\text { Source) } \\
\end{array}$ & $\begin{array}{l}\text { Study Design } \\
\text { (Sample Size) }\end{array}$ & Purpose & $\begin{array}{l}\text { Food Security } \\
\text { Measure }\end{array}$ & $\begin{array}{l}\text { Mental Health } \\
\text { Measure }\end{array}$ & $\begin{array}{l}\text { Mental Health } \\
\text { States/Conditions }\end{array}$ & Covariates Considered & $\begin{array}{l}\text { Analytic Approach and Key } \\
\text { Findings }\end{array}$ \\
\hline \multicolumn{9}{|c|}{ Abbreviated/adapted versions of Household Food Security Survey Module (HFSSM) } \\
\hline \multicolumn{9}{|c|}{ Longitudinal analyses } \\
\hline $\begin{array}{l}\text { Melchior et al. } \\
2009 \text { [44] }\end{array}$ & $\begin{array}{l}\text { Mothers of twins } \\
\text { (average 35.5 years) } \\
\text { from England and } \\
\text { Wales, Britain, included } \\
\text { White and non-White } \\
\text { races/ethnicities. } \\
\text { Environmental Risk } \\
\text { Study }\end{array}$ & $\begin{array}{l}\text { Longitudinal } \\
\text { (1116) }\end{array}$ & $\begin{array}{l}\text { Examine the association } \\
\text { between food insecurity } \\
\text { and maternal depression, } \\
\text { psychosis spectrum } \\
\text { disorder, alcohol or drug } \\
\text { abuse, and intimate } \\
\text { partner violence }\end{array}$ & $\begin{array}{l}\text { USDA HFSSM, } \\
\text { 7-item short } \\
\text { form }\end{array}$ & $\begin{array}{l}\text { Diagnostic } \\
\text { Interview } \\
\text { Schedule (DIS) }\end{array}$ & $\begin{array}{l}\text { Depressive } \\
\text { symptoms, } \\
\text { psychotic } \\
\text { symptoms }\end{array}$ & $\begin{array}{l}\text { Mother's age, income, } \\
\text { ethnicity, marital status, } \\
\text { household size, mother's } \\
\text { employment, mother's } \\
\text { reading ability }\end{array}$ & $\begin{array}{l}\text { Multivariable analyses: Food } \\
\text { insecurity increased the odds } \\
\text { of depression (OR } 2.12,95 \% \text { CI } \\
1.61-4.93 \text { ), intimate partner } \\
\text { violence (OR } 2.36,95 \% \text { CI } \\
1.18-4.73 \text { ), and psychosis (OR } \\
4.01,95 \% \text { CI 2.03-7.94) among } \\
\text { women two years later. Food } \\
\text { insecurity was associated with } \\
\text { mental illness comorbidity in } \\
\text { mothers-29\% of food-insecure } \\
\text { mothers had experienced } \\
\text { mental health problems or } \\
\text { intimate partner violence. }\end{array}$ \\
\hline $\begin{array}{l}\text { Sidebottom et al. } \\
2014 \text { [33] }\end{array}$ & $\begin{array}{l}\text { Pregnant women } \\
\text { (mean age, 22 years) } \\
\text { recruited from Health } \\
\text { Centres in Minneapolis } \\
\text { and St. Paul, US, } \\
\text { included African } \\
\text { American, American } \\
\text { Indian, Asian/Pacific } \\
\text { Islander, Hispanic (any } \\
\text { race), White, and } \\
\text { bi/multiracial women } \\
\text { Data from the Twin } \\
\text { Cities Healthy Start } \\
\text { Program }\end{array}$ & $\begin{array}{l}\text { Longitudinal } \\
\text { (prenatal and } \\
\text { postpartum } \\
\text { assessments) } \\
(594)\end{array}$ & $\begin{array}{l}\text { Examine correlates of } \\
\text { depression in pregnancy } \\
\text { and postpartum period }\end{array}$ & $\begin{array}{l}\text { USDA HFSSM, } \\
\text { 4-item subset }\end{array}$ & $\begin{array}{l}\text { PHQ-9 with } \\
\text { modification of } \\
\text { the item } \\
\text { measuring } \\
\text { psychomotor } \\
\text { issues (split into } \\
2 \text { questions but } \\
\text { scored as one) } \\
\text { Authors noted } \\
\text { sensitivity of } \\
77 \% \text {, specificity } \\
\text { of } 94 \% \text {, and } \\
\text { positive } \\
\text { predictive value } \\
\text { of } 59 \% \text { in } \\
\text { primary care } \\
\text { populations, } \\
\text { with higher } \\
\text { values in } \\
\text { populations } \\
\text { with a high } \\
\text { prevalence of } \\
\text { depressive } \\
\text { disorder }\end{array}$ & $\begin{array}{l}\text { Depressive } \\
\text { symptoms }\end{array}$ & $\begin{array}{l}\text { Age, race/ethnicity, } \\
\text { foreign-born, lack of social } \\
\text { support, abuse of any kind, } \\
\text { child protection } \\
\text { involvement, living with } \\
\text { child's father, drug, alcohol } \\
\text { and cigarette use, lack of } \\
\text { phone access, and housing } \\
\text { instability }\end{array}$ & $\begin{array}{l}\text { Multivariable analyses: } \\
\text { Compared to women who had } \\
\text { low depressive symptom levels } \\
\text { in both the prenatal and } \\
\text { postpartum periods, the odds } \\
\text { of elevated depressive } \\
\text { symptoms prenatally were } \\
\text { higher (aOR } 2.44,95 \% \text { CI } \\
1.43-4.16 \text { ) among those with } \\
\text { low levels of food security. } \\
\text { Food security and depressive } \\
\text { symptoms in the postpartum } \\
\text { period were not related. }\end{array}$ \\
\hline
\end{tabular}


Table A1. Cont.

\begin{tabular}{|c|c|c|c|c|c|c|c|c|}
\hline Reference & $\begin{array}{l}\text { Sample (Participants } \\
\text { (Age), Setting, } \\
\text { Race/Ethnicity, Data } \\
\text { Source) }\end{array}$ & $\begin{array}{l}\text { Study Design } \\
\text { (Sample Size) }\end{array}$ & Purpose & $\begin{array}{l}\text { Food Security } \\
\text { Measure }\end{array}$ & $\begin{array}{l}\text { Mental Health } \\
\text { Measure }\end{array}$ & $\begin{array}{c}\text { Mental Health } \\
\text { States/Conditions }\end{array}$ & Covariates Considered & $\begin{array}{l}\text { Analytic Approach and Key } \\
\text { Findings }\end{array}$ \\
\hline \multicolumn{9}{|c|}{ Cross-sectional analyses } \\
\hline $\begin{array}{l}\text { Whitaker et al. } \\
2006 \text { [59] }\end{array}$ & $\begin{array}{l}\text { Mothers (18+ years) of } \\
3 \text {-year old children, } \\
\text { recruited from } 75 \text { birth } \\
\text { hospitals in } 20 \text { US cities. } \\
\text { Included White, } \\
\text { African American, } \\
\text { Hispanic, other } \\
\text { races/ethnicities } \\
\text { Fragile Families and } \\
\text { Child Wellbeing Study }\end{array}$ & $\begin{array}{l}\text { Cross-sectional } \\
(2870)\end{array}$ & $\begin{array}{l}\text { Examine if food security } \\
\text { is associated with } \\
\text { prevalence of depression } \\
\text { and anxiety in mothers } \\
\text { and behavior problems in } \\
\text { children }\end{array}$ & $\begin{array}{l}\text { USDA HFSSM, } \\
10 \\
\text { adult-referenced } \\
\text { items }\end{array}$ & $\begin{array}{l}\text { CIDI short form } \\
\text { administered } 3 \\
\text { years after } \\
\text { child's birth, } \\
\text { modified cut-off } \\
\text { for a major } \\
\text { depressive } \\
\text { episode (MDE) } \\
\text { based on } \\
\text { symptoms of } \\
\text { anhedonia }\end{array}$ & $\begin{array}{l}\text { Clinical diagnosis } \\
\text { of a MDE or } \\
\text { generalized } \\
\text { anxiety disorder } \\
\text { (GAD) in the prior } \\
12 \text { months }\end{array}$ & $\begin{array}{l}\text { Mother's education, } \\
\text { race/ethnicity, relationship } \\
\text { status, employment in } \\
\text { previous year, binge } \\
\text { drinking, illicit drug use, } \\
\text { global health, prenatal } \\
\text { smoking, prenatal physical } \\
\text { domestic violence, } \\
\text { household income/poverty } \\
\text { ratio, number of children, } \\
\text { non-food related material } \\
\text { hardship, and whether } \\
\text { father was ever in jail }\end{array}$ & $\begin{array}{l}\text { Multivariable analyses: } \\
\text { Compared to fully food-secure } \\
\text { mothers, experiencing } \\
\text { marginal food insecurity } \\
\text { increased the odds of } \\
\text { experiencing an MDE or GAD } \\
\text { (aOR 1.4, 95\% CI 1.1-1.8; and } \\
\text { aOR 1.7, } 95 \% \text { CI 1.0-2.7, } \\
\text { respectively). Compared to } \\
\text { fully food-secure mothers, } \\
\text { experiencing food insecurity } \\
\text { increased the odds of } \\
\text { experiencing an MDE or GAD } \\
\text { (aOR 2.2, 95\% CI 1.6-2.9; and } \\
\text { aOR 2.3, 95\% CI 1.5-3.6 } \\
\text { respectively). Mothers } \\
\text { experiencing food insecurity } \\
\text { twice as likely to also } \\
\text { experience either MDE or GAD } \\
\text { compared to food-secure } \\
\text { mothers (aOR 2.2, 95\% CI } \\
\text { 1.6-2.9). }\end{array}$ \\
\hline $\begin{array}{l}\text { Laraia et al. } \\
2009[58]\end{array}$ & $\begin{array}{l}\text { African American, } \\
\text { first-time mothers } \\
\text { (18-35 years) recruited } \\
\text { from Special } \\
\text { Supplemental Nutrition } \\
\text { Program for Women, } \\
\text { Children, and Infants } \\
\text { (WIC) clinics in North } \\
\text { Carolina, US } \\
\text { Infant Care, Feeding, } \\
\text { and Risk of Obesity } \\
\text { observational study }\end{array}$ & $\begin{array}{l}\text { Cross-sectional } \\
\text { analysis of } \\
\text { longitudinal } \\
\text { study, focused } \\
\text { on 3-month } \\
\text { postpartum } \\
\text { baseline data } \\
\text { (206) }\end{array}$ & $\begin{array}{l}\text { Identify maternal and } \\
\text { household correlates of } \\
\text { food insecurity among } \\
\text { African-American } \\
\text { mothers }\end{array}$ & $\begin{array}{l}\text { USDA HFSSM, } \\
\text { 6-item short } \\
\text { form }\end{array}$ & $\begin{array}{l}\text { CES-D, } \\
\text { Rosenberg } \\
\text { Self-Esteem } \\
\text { Scale }\end{array}$ & $\begin{array}{l}\text { Depressive } \\
\text { symptoms and } \\
\text { self-esteem }\end{array}$ & $\begin{array}{l}\text { Maternal age, education, } \\
\text { work status, depression } \\
\text { score, and self-esteem, as } \\
\text { well as household } \\
\text { composition (presence of } \\
\text { father, grandmother and } \\
\text { household size) }\end{array}$ & $\begin{array}{l}\text { Bivariate analyses: Women } \\
\text { living in food-insecure } \\
\text { households had significantly } \\
\text { higher scores on the depressive } \\
\text { scale compared to food-secure } \\
\text { women }(p<0.05) \text {. } \\
\text { Multivariable analyses: } \\
\text { Depressive symptoms were } \\
\text { associated with marginal food } \\
\text { security and food insecurity } \\
\text { (aRRR }{ }^{*} 1.04,95 \% \text { CI } 1.00-1.08 \\
\text { and aRRR* } 1.10,95 \% \text { CI } \\
1.04-1.16, \text { respectively). } \\
\text { Self-esteem scores were } \\
\text { negatively associated with risk } \\
\text { for marginal food security and } \\
\text { food insecurity (aRRR } 0.91 \text {, } \\
95 \% \text { CI 0.84-0.98, and aRRR* } \\
0.89,95 \% \text { CI } 0.79-0.99, \\
\text { respectively)* aRRR }= \\
\text { adjusted Relative Risk Ratio. }\end{array}$ \\
\hline
\end{tabular}


Table A1. Cont.

\begin{tabular}{|c|c|c|c|c|c|c|c|c|}
\hline Reference & $\begin{array}{l}\text { Sample (Participants } \\
\text { (Age), Setting, } \\
\text { Race/Ethnicity, Data } \\
\text { Source) }\end{array}$ & $\begin{array}{l}\text { Study Design } \\
\text { (Sample Size) }\end{array}$ & Purpose & $\begin{array}{l}\text { Food Security } \\
\text { Measure }\end{array}$ & $\begin{array}{l}\text { Mental Health } \\
\text { Measure }\end{array}$ & $\begin{array}{l}\text { Mental Health } \\
\text { States/Conditions }\end{array}$ & Covariates Considered & $\begin{array}{l}\text { Analytic Approach and Key } \\
\text { Findings }\end{array}$ \\
\hline $\begin{array}{l}\text { Mathews et al. } \\
2010[34]\end{array}$ & $\begin{array}{l}\text { Mothers (<25 years) } \\
\text { recruited from the } \\
\text { Special Supplemental } \\
\text { Nutrition Program for } \\
\text { Women, Infants, and } \\
\text { Children (WIC) clinics } \\
\text { in Butte County, } \\
\text { California, US, included } \\
\text { White, non-White } \\
\text { races/ethnicities }\end{array}$ & $\begin{array}{l}\text { Cross-sectional } \\
\text { (155) }\end{array}$ & $\begin{array}{l}\text { Evaluate the prevalence } \\
\text { of and associations } \\
\text { between food insecurity } \\
\text { and health status among } \\
\text { women participating in } \\
\text { WIC }\end{array}$ & $\begin{array}{l}\text { USDA HFSSM, } \\
\text { 6-item short } \\
\text { form }\end{array}$ & $\begin{array}{l}\text { SF-12 Health } \\
\text { Survey } \\
\text { Authors noted } \\
\text { that the SF-12 } \\
\text { has been } \\
\text { validated } \\
\text { previously }\end{array}$ & $\begin{array}{l}\text { General mental } \\
\text { (and physical) } \\
\text { health symptoms }\end{array}$ & $\begin{array}{l}\text { Diet choice score, income, } \\
\text { ethnicity, age, education }\end{array}$ & $\begin{array}{l}\text { Bivariate analyses: Women } \\
\text { experiencing low or very low } \\
\text { food insecurity had } \\
\text { significantly lower mental } \\
\text { health scores, indicating more } \\
\text { mental health symptoms } \\
\text { compared to food-secure } \\
\text { women }(p<0.001) \text {. The } \\
\text { correlation between food } \\
\text { insecurity and mental health } \\
\text { scores indicates that as } \\
\text { women's food security } \\
\text { increased, mental health also } \\
\text { increases. Multivariable } \\
\text { analyses: The likelihood of } \\
\text { having a good mental health } \\
\text { score was lower (OR } 0.41,95 \% \\
\text { CI } 0.16-0.73 \text { ) among those in } \\
\text { food-insecure versus those in } \\
\text { food-secure households. }\end{array}$ \\
\hline $\begin{array}{l}\text { Ajrouch et al. } \\
2010[35]\end{array}$ & $\begin{array}{l}\text { Female } \\
\text { African-American } \\
\text { caregivers (mean age, } \\
30.8 \text { years) of young } \\
\text { children recruited from } \\
\text { high-poverty census } \\
\text { tracts in Detroit, US } \\
\text { Detroit Centre for } \\
\text { Research on Oral } \\
\text { Health Disparities. }\end{array}$ & $\begin{array}{l}\text { Cross-sectional } \\
\text { (multiple waves } \\
\text { of data } \\
\text { collection, } \\
\text { relevant } \\
\text { variables were } \\
\text { assessed in } \\
\text { wave 2) (736) }\end{array}$ & $\begin{array}{l}\text { Explore link between } \\
\text { situational stressors, } \\
\text { including food } \\
\text { insufficiency, and } \\
\text { psychological distress, } \\
\text { and examine social } \\
\text { support as a potential } \\
\text { mediator }\end{array}$ & $\begin{array}{l}\text { USDA HFSSM, } \\
\text { 3-item subset } \\
\text { (referred to as } \\
\text { food } \\
\text { insufficiency) } \\
\text { Cronbach's } \\
\text { alpha reported } \\
\text { as } 0.79\end{array}$ & $\begin{array}{l}\text { CES-D 20-item } \\
\text { Authors noted } \\
\text { high internal } \\
\text { reliability in this } \\
\text { sample }\end{array}$ & $\begin{array}{l}\text { Depressive } \\
\text { symptoms }\end{array}$ & $\begin{array}{l}\text { Age, self-rated health, and } \\
\text { education level }\end{array}$ & $\begin{array}{l}\text { Multivariable analyses: Higher } \\
\text { food insufficiency associated } \\
\text { with higher depressive } \\
\text { symptoms (referred to as } \\
\text { psychological distress) } \\
(\beta=2.88, p<0.001) \text {. At high } \\
\text { levels of stress, social support } \\
\text { was not a mediator of this } \\
\text { relationship. }\end{array}$ \\
\hline $\begin{array}{l}\text { Hromi-Fielder } \\
\text { et al. } 2011 \text { [36] }\end{array}$ & $\begin{array}{l}\text { Low income, pregnant } \\
\text { Latina women (mean } \\
\text { age, } 25 \text { years), recruited } \\
\text { from local agencies and } \\
\text { programs in Hartford, } \\
\text { Connecticut, US. }\end{array}$ & $\begin{array}{l}\text { Cross-sectional } \\
(135)\end{array}$ & $\begin{array}{l}\text { Assess relationship } \\
\text { between household food } \\
\text { insecurity and prenatal } \\
\text { depressive symptoms }\end{array}$ & $\begin{array}{l}\text { USDA HFSSM, } \\
\text { 15-item subset } \\
\text { adapted version } \\
\text { for pregnant } \\
\text { Latinas } \\
\text { Authors note } \\
\text { that the adapted } \\
\text { version was } \\
\text { validated for } \\
\text { this population }\end{array}$ & $\begin{array}{l}\text { CES-D 20-item } \\
\text { Authors note } \\
\text { that the CES-D } \\
\text { has been } \\
\text { validated with } \\
\text { multi-ethnic } \\
\text { samples, } \\
\text { including } \\
\text { Mexican-Americans }\end{array}$ & $\begin{array}{l}\text { Prenatal } \\
\text { depressive } \\
\text { symptoms }\end{array}$ & $\begin{array}{l}\text { Parity, heartburn during } \\
\text { pregnancy, self-reported } \\
\text { health during pregnancy, } \\
\text { history of depression, } \\
\text { Latina subgroup, } \\
\text { acculturation }\end{array}$ & $\begin{array}{l}\text { Multivariable analyses: } \\
\text { Women experiencing food } \\
\text { insecurity were more likely to } \\
\text { report high levels of prenatal } \\
\text { depressive symptoms } \\
\text { compared to those who were } \\
\text { food secure (aOR } 2.59,95 \% \text { CI } \\
\text { 1.03-6.52). }\end{array}$ \\
\hline
\end{tabular}


Table A1. Cont.

\begin{tabular}{|c|c|c|c|c|c|c|c|c|}
\hline Reference & $\begin{array}{c}\text { Sample (Participants } \\
\text { (Age), Setting, } \\
\text { Race/Ethnicity, Data } \\
\text { Source) }\end{array}$ & $\begin{array}{l}\text { Study Design } \\
\text { (Sample Size) }\end{array}$ & Purpose & $\begin{array}{l}\text { Food Security } \\
\text { Measure }\end{array}$ & $\begin{array}{l}\text { Mental Health } \\
\text { Measure }\end{array}$ & $\begin{array}{l}\text { Mental Health } \\
\text { States/Conditions }\end{array}$ & Covariates Considered & $\begin{array}{l}\text { Analytic Approach and Key } \\
\text { Findings }\end{array}$ \\
\hline $\begin{array}{l}\text { Harrison et al. } \\
2008 \text { [60] }\end{array}$ & $\begin{array}{l}\text { Pregnant women in } \\
\text { Minneapolis and St. } \\
\text { Paul, US, included } \\
\text { African American, } \\
\text { Asian/Pacific Islander, } \\
\text { Hispanic, American } \\
\text { Indian, White, } \\
\text { bi/multiracial } \\
\text { races/ethnicities. } \\
\text { recruited from } \\
\text { Federally Qualified } \\
\text { Health Centres } \\
\text { Feasibility study } \\
\text { associated with Twin } \\
\text { Cities Healthy Start } \\
\text { Program }\end{array}$ & $\begin{array}{l}\text { Cross-sectional } \\
(1386)\end{array}$ & $\begin{array}{l}\text { Examine the prevalence, } \\
\text { co-occurrence, and } \\
\text { inter-correlations of } \\
\text { self-reported } \\
\text { psychosocial risk factors, } \\
\text { including food insecurity. }\end{array}$ & $\begin{array}{l}\text { USDA HFSSM, } \\
\text { 4-item subset }\end{array}$ & $\begin{array}{l}\text { PHQ-9, intimate } \\
\text { partner violence } \\
\text { items, } 8 \text { items } \\
\text { from the } \\
\text { Maternal Social } \\
\text { Support Index } \\
\text { Authors note } \\
\text { high levels of } \\
\text { internal } \\
\text { reliability, } \\
\text { test-retest } \\
\text { reliability, } \\
\text { sensitivity, and } \\
\text { specificity for } \\
\text { PHQ-9 }\end{array}$ & $\begin{array}{l}\text { Depressive } \\
\text { symptoms }\end{array}$ & Not applicable & $\begin{array}{l}\text { Bivariate analyses: Depressive } \\
\text { symptoms }(\mathrm{r}=0.267) \text {, social } \\
\text { support }(\mathrm{r}=0.194) \text {, and } \\
\text { intimate partner violence } \\
(\mathrm{r}=0.173) \text { were significantly } \\
\text { correlated }(p \leq 0.0001) \text { with } \\
\text { household food insecurity. }\end{array}$ \\
\hline $\begin{array}{l}\text { Martin et al. } \\
2016 \text { [17] }\end{array}$ & $\begin{array}{l}\text { Adults (18-75 years), } \\
\text { Canada } \\
\text { Data from the } \\
\text { 2009-2010 Canadian } \\
\text { Community Health } \\
\text { Survey }\end{array}$ & $\begin{array}{l}\text { Cross-sectional } \\
(100,401)\end{array}$ & $\begin{array}{l}\text { To examine the } \\
\text { co-occurrence of food } \\
\text { insecurity and mental } \\
\text { illness across varying } \\
\text { levels of stress and } \\
\text { community belonging }\end{array}$ & $\begin{array}{l}\text { USDA HFSSM, } \\
10 \\
\text { adult-referenced } \\
\text { items (Health } \\
\text { Canada coding) }\end{array}$ & $\begin{array}{l}\text { Self-reported } \\
\text { diagnosis of a } \\
\text { mood or anxiety } \\
\text { disorder, } \\
\text { subsample } \\
(n=47,942) \\
\text { completed CIDI } \\
\text { short form, one } \\
\text { item for each of } \\
\text { perceived stress } \\
\text { and community } \\
\text { belonging }\end{array}$ & $\begin{array}{l}\text { Clinical diagnosis } \\
\text { of a mood } \\
\text { disorder such as } \\
\text { depression, } \\
\text { bipolar disorder, } \\
\text { mania, or } \\
\text { dysthymia; or an } \\
\text { anxiety disorder } \\
\text { such as phobia, } \\
\text { obsessive-compulsive } \\
\text { disorder, or panic } \\
\text { disorder. Past 12 } \\
\text { months of major } \\
\text { depression from } \\
\text { CIDI short form. }\end{array}$ & $\begin{array}{l}\text { Age, marital status, } \\
\text { children in house, } \\
\text { household income, } \\
\text { education, unemployment, } \\
\text { and self-perceived physical } \\
\text { health, as well as overall } \\
\text { estress level and community } \\
\text { belonging. }\end{array}$ & $\begin{array}{l}\text { Multivariable analyses: } \\
\text { Women living in severely } \\
\text { food-insecure households had } \\
18.4 \% \text { ( } 95 \% \text { CI } 16.7-20.1) \\
\text { greater adjusted prevalence of } \\
\text { a mental disorder compared to } \\
\text { those living in food-secure } \\
\text { households. The prevalence of } \\
\text { women reporting high levels of } \\
\text { stress increased with } \\
\text { worsening food security. } \\
\text { Greater proportions of severely } \\
\text { food-insecure women reported } \\
\text { low community belonging } \\
\text { compared to more food-secure } \\
\text { women. Interaction between } \\
\text { community belonging, food } \\
\text { insecurity, and perceived stress } \\
\text { not significant. }\end{array}$ \\
\hline
\end{tabular}


Table A1. Cont.

\begin{tabular}{|c|c|c|c|c|c|c|c|c|}
\hline Reference & $\begin{array}{c}\text { Sample (Participants } \\
\text { (Age), Setting, } \\
\text { Race/Ethnicity, Data } \\
\text { Source) }\end{array}$ & $\begin{array}{l}\text { Study Design } \\
\text { (Sample Size) }\end{array}$ & Purpose & $\begin{array}{l}\text { Food Security } \\
\text { Measure }\end{array}$ & $\begin{array}{l}\text { Mental Health } \\
\text { Measure }\end{array}$ & $\begin{array}{l}\text { Mental Health } \\
\text { States/Conditions }\end{array}$ & Covariates Considered & $\begin{array}{l}\text { Analytic Approach and Key } \\
\text { Findings }\end{array}$ \\
\hline $\begin{array}{l}\text { Dressler et al. } \\
2015 \text { [37] }\end{array}$ & $\begin{array}{l}\text { Low-income women } \\
\text { ( } 18-64 \text { years) recruited } \\
\text { from homeless shelters, } \\
\text { food pantries, libraries, } \\
\text { soup kitchens, and } \\
\text { community centers, US, } \\
\text { included African } \\
\text { American, White, } \\
\text { Native American } \\
\text { women }\end{array}$ & $\begin{array}{l}\text { Cross-sectional } \\
(330)\end{array}$ & $\begin{array}{l}\text { Examine depression and } \\
\text { its relationship with food } \\
\text { insecurity, weight status, } \\
\text { emotional eating, and } \\
\text { dietary intake among } \\
\text { low-income women }\end{array}$ & $\begin{array}{l}\text { USDA HFSSM, } \\
\text { 6-item short } \\
\text { form }\end{array}$ & $\begin{array}{l}\text { CES-D 20-item, } \\
\text { emotional } \\
\text { eating questions } \\
\text { developed } \\
\text { using validated } \\
\text { questionnaires } \\
\text { Authors note } \\
\text { that the CES-D } \\
\text { is valid and } \\
\text { reliable and } \\
\text { note the internal } \\
\text { consistency in } \\
\text { the sample for } \\
\text { both the CES-D } \\
\text { and the } \\
\text { emotional } \\
\text { eating questions }\end{array}$ & $\begin{array}{l}\text { Symptoms of } \\
\text { depression and } \\
\text { emotional eating }\end{array}$ & Not applicable & $\begin{array}{l}\text { Bivariate analyses: Women } \\
\text { categorized as depressed had } \\
\text { higher food insecurity scores } \\
\text { compared to women who were } \\
\text { not depressed ( } 3.2 \text { vs. } 1.9 \text {, } \\
p<0.05) \text {. Depression and } \\
\text { emotional eating were also } \\
\text { associated. }\end{array}$ \\
\hline $\begin{array}{l}\text { Kaiser et al. } \\
2007 \text { [57] }\end{array}$ & $\begin{array}{l}\text { Women (18+ years) } \\
\text { living in California, US, } \\
\text { included White, } \\
\text { African American, } \\
\text { Hispanic/Latino, and } \\
\text { other races/ethnicities. } \\
2004 \text { California } \\
\text { Women's Health } \\
\text { Survey }\end{array}$ & $\begin{array}{l}\text { Cross-sectional } \\
(4037)\end{array}$ & $\begin{array}{l}\text { Identify factors } \\
\text { associated with food } \\
\text { insecurity }\end{array}$ & $\begin{array}{l}\text { USDA HFSSM, } \\
6 \text {-item subset, } \\
\text { modified to } \\
\text { refer to } \\
\text { respondent and } \\
\text { not to other } \\
\text { adults in } \\
\text { household }\end{array}$ & $\begin{array}{l}\text { Indicators of } \\
\text { mental or } \\
\text { emotional } \\
\text { problems }\end{array}$ & $\begin{array}{l}\text { Mental, (physical), } \\
\text { or emotional } \\
\text { problems that } \\
\text { interfere with } \\
\text { daily life, feeling } \\
\text { depressed or sad, } \\
\text { and feeling } \\
\text { overwhelmed }\end{array}$ & $\begin{array}{l}\text { Income as a proportion of } \\
\text { the federal poverty ratio }\end{array}$ & $\begin{array}{l}\text { Multivariable analyses: Higher } \\
\text { food insecurity was associated } \\
\text { with feeling depressed or sad } \\
\text { for 2+ days in the prior month } \\
\text { (aOR 1.61, 95\% CI 1.28-2.02), } \\
\text { feeling overwhelmed in past } \\
30 \text { days (aOR 3.10, 95\% CI } \\
\text { 2.49-3.85), and reporting that } \\
\text { physical or mental health } \\
\text { conditions interfered with } \\
\text { normal activities in past } 30 \\
\text { days (aOR 1.81, 95\% CI } \\
1.45-2.27) \text {. }\end{array}$ \\
\hline $\begin{array}{l}\text { Peterman et al. } \\
2013[38]\end{array}$ & $\begin{array}{l}\text { Cambodian women } \\
\text { ( } 30-65 \text { years) recruited } \\
\text { from clients of the } \\
\text { Cambodian Mutual } \\
\text { Assurance Association } \\
\text { of Lowell, } \\
\text { Massachusetts, US } \\
\text { Cambodian } \\
\text { Community Health } \\
\text { Program } 2010\end{array}$ & $\begin{array}{l}\text { Cross-sectional } \\
(150)\end{array}$ & $\begin{array}{l}\text { Examine } \\
\text { post-immigration } \\
\text { experiences with food, } \\
\text { food security status, and } \\
\text { correlates among refugee } \\
\text { women }\end{array}$ & $\begin{array}{l}\text { USDA HFSSM, } \\
\text { 6-item short } \\
\text { form }\end{array}$ & $\begin{array}{l}\text { Harvard } \\
\text { Program in } \\
\text { Refugee } \\
\text { Trauma's } \\
\text { depression scale; } \\
14 \text { items, } \\
\text { previously } \\
\text { translated and } \\
\text { validated for } \\
\text { use in } \\
\text { Cambodian } \\
\text { refugee } \\
\text { populations }\end{array}$ & $\begin{array}{l}\text { Clinical diagnosis } \\
\text { of depression }\end{array}$ & $\begin{array}{l}\text { Marital status, receipt of } \\
\text { food stamps, income to } \\
\text { poverty ratio, acculturation, } \\
\text { age }\end{array}$ & $\begin{array}{l}\text { Multivariable analyses: } \\
\text { Women experiencing } \\
\text { marginal/low/very low food } \\
\text { security were more likely (aOR } \\
3.73,95 \% \text { CI 1.26-11.05) to be } \\
\text { classified as depressed } \\
\text { compared to those in } \\
\text { food-secure households. }\end{array}$ \\
\hline
\end{tabular}


Table A1. Cont.

\begin{tabular}{|c|c|c|c|c|c|c|c|c|}
\hline Reference & $\begin{array}{l}\text { Sample (Participants } \\
\text { (Age), Setting, } \\
\text { Race/Ethnicity, Data } \\
\text { Source) }\end{array}$ & $\begin{array}{l}\text { Study Design } \\
\text { (Sample Size) }\end{array}$ & Purpose & $\begin{array}{l}\text { Food Security } \\
\text { Measure }\end{array}$ & $\begin{array}{l}\text { Mental Health } \\
\text { Measure }\end{array}$ & $\begin{array}{l}\text { Mental Health } \\
\text { States/Conditions }\end{array}$ & Covariates Considered & $\begin{array}{l}\text { Analytic Approach and Key } \\
\text { Findings }\end{array}$ \\
\hline $\begin{array}{l}\text { Sharpe et al. } \\
2016 \text { [39] }\end{array}$ & $\begin{array}{l}\text { Low-income women } \\
\text { ( } 25-51 \text { years) recruited } \\
\text { from } 18 \text { census tracts in } \\
\text { which } 25 \% \text { or more of } \\
\text { residents had } \\
\text { below-poverty income } \\
\text { in South Carolina, US, } \\
\text { mainly } \\
\text { African-American } \\
\text { Sisters Taking Action } \\
\text { for Real Success } \\
\text { (STARS) trial }\end{array}$ & $\begin{array}{l}\text { Cross-sectional } \\
\text { (202) }\end{array}$ & $\begin{array}{l}\text { Examine whether on diet } \\
\text { quality and psychosocial } \\
\text { and behavioral factors } \\
\text { are associated with } \\
\text { household food security }\end{array}$ & $\begin{array}{l}\text { USDA HFSSM, } \\
\text { 6-item short } \\
\text { form }\end{array}$ & $\begin{array}{l}\text { CES-D 10 item, } \\
\text { emotional } \\
\text { eating subscale } \\
\text { of the Eating } \\
\text { Behavior } \\
\text { Patterns } \\
\text { Questionnaire } \\
\text { Authors noted } \\
\text { that the } \\
\text { CESD-10 has } \\
\text { been validated } \\
\text { and that the } \\
\text { Eating Behavior } \\
\text { Patterns } \\
\text { Questionnaire } \\
\text { has been shown } \\
\text { to have } \\
\text { acceptable } \\
\text { internal } \\
\text { consistency and } \\
\text { construct } \\
\text { validity in } \\
\text { African-American } \\
\text { women; authors } \\
\text { also identified } \\
\text { Cronbach's } \\
\text { alphas for both } \\
\text { measures in the } \\
\text { study sample }\end{array}$ & $\begin{array}{l}\text { Symptoms of } \\
\text { depression and } \\
\text { emotional eating }\end{array}$ & Not applicable & $\begin{array}{l}\text { Bivariate analyses: Women } \\
\text { experiencing food insecurity } \\
\text { had significantly higher scores } \\
\text { for depressive symptoms } \\
\text { (indicating more symptoms) } \\
\text { compared to women living in } \\
\text { food-secure households (mean } \\
\text { score } 10.9 \text { (SD 6.1) vs. 8.3 (SD } \\
5.0 \text { ), } \mathrm{t}=3.36, p<0.001 \text { ). Women } \\
\text { experiencing food insecurity } \\
\text { had significantly lower } \\
\text { emotional eating scores } \\
\text { (indicating higher levels of } \\
\text { emotional eating) compared to } \\
\text { women living in food-secure } \\
\text { households (mean score } 10.2 \\
\text { (SD 3.1) vs. 11.4 (SD 3.8), } \\
\mathrm{t}=2.45, p<0.02 \text { ). }\end{array}$ \\
\hline $\begin{array}{l}\text { Davey-Rothwell } \\
\text { et al. } 2014 \text { [40] }\end{array}$ & $\begin{array}{l}\text { Low-income women } \\
\text { (18-55 years) at risk for } \\
\text { HIV, recruited through } \\
\text { street outreach and } \\
\text { public advertisements } \\
\text { in the US, majority } \\
\text { African-American } \\
\text { women } \\
\text { Data from the CHAT } \\
\text { study }\end{array}$ & $\begin{array}{l}\text { Cross-sectional } \\
\text { (based on } \\
6 \text {-month visit) } \\
(443)\end{array}$ & $\begin{array}{l}\text { Explore food insecurity } \\
\text { among drug-using and } \\
\text { non-drug-using women } \\
\text { and examine the } \\
\text { relationship between } \\
\text { depression and food } \\
\text { insecurity }\end{array}$ & $\begin{array}{l}\text { USDA HFSSM, } \\
\text { 4-item subset } \\
\text { Authors noted } \\
\text { acceptable } \\
\text { internal } \\
\text { consistency in } \\
\text { this sample }\end{array}$ & $\begin{array}{l}\text { CES-D 20-item } \\
\text { Authors noted } \\
\text { high internal } \\
\text { consistency in } \\
\text { this sample }\end{array}$ & $\begin{array}{l}\text { Depressive } \\
\text { symptoms }\end{array}$ & $\begin{array}{l}\text { Age, race, income, receipt } \\
\text { of food stamps }\end{array}$ & $\begin{array}{l}\text { Multivariable analyses: } \\
\text { Drug-users were 2.71 times } \\
\text { (aOR, 95\% CI 1.51-4.88), and } \\
\text { non-drug-users were 5.9 times } \\
\text { (aOR, 95\% CI 2.80-12.45) more } \\
\text { likely to experience depression } \\
\text { if they were food insecure } \\
\text { compared to food secure. }\end{array}$ \\
\hline
\end{tabular}


Table A1. Cont.

\begin{tabular}{|c|c|c|c|c|c|c|c|c|}
\hline Reference & $\begin{array}{c}\text { Sample (Participants } \\
\text { (Age), Setting, } \\
\text { Race/Ethnicity, Data } \\
\text { Source) }\end{array}$ & $\begin{array}{l}\text { Study Design } \\
\text { (Sample Size) }\end{array}$ & Purpose & $\begin{array}{l}\text { Food Security } \\
\text { Measure }\end{array}$ & $\begin{array}{l}\text { Mental Health } \\
\text { Measure }\end{array}$ & $\begin{array}{c}\text { Mental Health } \\
\text { States/Conditions }\end{array}$ & Covariates Considered & $\begin{array}{l}\text { Analytic Approach } \\
\text { and Key Findings }\end{array}$ \\
\hline \multicolumn{9}{|c|}{ Radimer-Cornell Scale } \\
\hline \multicolumn{9}{|c|}{ Cross-sectional analyses } \\
\hline $\begin{array}{l}\text { Sharkey et al. } \\
2011 \text { [41] }\end{array}$ & $\begin{array}{l}\text { Urban and rural } \\
\text { women (18+ years) } \\
\text { living in Brazos Valley, } \\
\text { Texas, US, included } \\
\text { White and non-White } \\
\text { races/ethnicities } \\
\text { Brazos Valley Health } \\
\text { Status Assessment }\end{array}$ & $\begin{array}{l}\text { Cross-sectional } \\
\text { (1367) }\end{array}$ & $\begin{array}{l}\text { Examine health status, } \\
\text { mental distress, and } \\
\text { household food } \\
\text { insecurity among urban } \\
\text { and rural women }\end{array}$ & $\begin{array}{l}\text { Radimer-Cornell } \\
\text { Scale, first item } \\
\text { focused on food } \\
\text { deprivation (food } \\
\text { we bought did not } \\
\text { last and we did } \\
\text { not have enough } \\
\text { money to buy } \\
\text { more) was used to } \\
\text { determine } \\
\text { presence of } \\
\text { household food } \\
\text { insecurity } \\
\text { Authors noted } \\
\text { that the Scale has } \\
\text { been shown to be } \\
\text { valid for } \\
\text { non-white } \\
\text { participants }\end{array}$ & $\begin{array}{l}\text { Centre for Disease } \\
\text { Control (CDC) and } \\
\text { the Behavioral Risk } \\
\text { Factor Surveillance } \\
\text { Systems (BRFSS) } \\
\text { questionnaire to } \\
\text { assess health-related } \\
\text { quality of life } \\
\text { (perceived } \\
\text { mental—and general } \\
\text { and } \\
\text { physical-well-being } \\
\text {-thinking about your } \\
\text { mental health, which } \\
\text { includes stress, } \\
\text { depression, and } \\
\text { problems with } \\
\text { emotions, for how } \\
\text { many days during the } \\
\text { past } 30 \text { days was your } \\
\text { mental health not } \\
\text { good?) } \\
\text { Authors noted that } \\
\text { the measures have } \\
\text { been shown to be } \\
\text { valid for non-white } \\
\text { populations }\end{array}$ & $\begin{array}{l}\text { Perceived mental } \\
\text { health (stress, } \\
\text { depression, } \\
\text { problems with } \\
\text { emotions), } \\
\text { referred to as } \\
\text { frequent mental } \\
\text { distress }\end{array}$ & $\begin{array}{l}\text { Age, race, education, } \\
\text { annual household income, } \\
\text { employment, rural vs. } \\
\text { urban geographic location }\end{array}$ & $\begin{array}{l}\text { Multivariable analyses } \\
\text { Women experiencing } \\
\text { food insecurity in the } \\
\text { last } 30 \text { days were more } \\
\text { likely to frequently } \\
\text { experience mental } \\
\text { distress compared to } \\
\text { food-secure women } \\
\text { (aOR } 2.25,95 \% \text { CI } \\
1.59-3.18 \text { ). }\end{array}$ \\
\hline
\end{tabular}


Table A1. Cont.

\begin{tabular}{|c|c|c|c|c|c|c|c|c|}
\hline Reference & $\begin{array}{l}\text { Sample (Participants } \\
\text { (Age), Setting, } \\
\text { Race/Ethnicity, Data } \\
\text { Source) }\end{array}$ & $\begin{array}{l}\text { Study Design } \\
\text { (Sample Size) }\end{array}$ & Purpose & $\begin{array}{l}\text { Food Security } \\
\text { Measure }\end{array}$ & $\begin{array}{l}\text { Mental Health } \\
\text { Measure }\end{array}$ & $\begin{array}{l}\text { Mental Health } \\
\text { States/Conditions }\end{array}$ & Covariates Considered & $\begin{array}{l}\text { Analytic Approach and Key } \\
\text { Findings }\end{array}$ \\
\hline \multicolumn{9}{|c|}{ Community Childhood Hunger Identification Project (CCHIP) measure } \\
\hline \multicolumn{9}{|c|}{ Cross-sectional analyses } \\
\hline $\begin{array}{l}\text { Wehler et al. } \\
2004 \text { [52] }\end{array}$ & $\begin{array}{l}\text { Homeless and housed } \\
\text { women (mean age, } \\
28 \text { years) recruited from } \\
\text { Worcester's homeless } \\
\text { shelters and welfare } \\
\text { hostels and the } \\
\text { Department of Public } \\
\text { Welfare office, US, } \\
\text { included White, } \\
\text { African American, } \\
\text { Hispanic, and other } \\
\text { races/ethnicities. } \\
\text { Worcester Family } \\
\text { Research Project }\end{array}$ & $\begin{array}{l}\text { Cross-sectional } \\
(354)\end{array}$ & $\begin{array}{l}\text { Examine factors } \\
\text { associated with adult or } \\
\text { child hunger among } \\
\text { low-income housed and } \\
\text { homeless female-headed } \\
\text { families }\end{array}$ & $\begin{array}{l}\text { CCHIP, } 7 \text { items } \\
\text { querying adult } \\
\text { and child } \\
\text { hunger } \\
\text { Authors noted } \\
\text { high level of } \\
\text { internal } \\
\text { consistency and } \\
\text { factor analysis } \\
\text { indicated a } \\
\text { single-factor } \\
\text { solution }\end{array}$ & $\begin{array}{l}\text { Structured } \\
\text { Clinical } \\
\text { Interview for } \\
\text { Diagnostic } \\
\text { Statistical } \\
\text { Manual } \\
\text { (DSM-III-R } \\
\text { non-patient } \\
\text { edition), Life } \\
\text { Experiences } \\
\text { Survey }\end{array}$ & $\begin{array}{l}\text { Clinical diagnosis } \\
\text { of substance use, } \\
\text { depression, } \\
\text { posttraumatic } \\
\text { stress disorder } \\
\text { (PTSD), major life } \\
\text { events in } \\
\text { adulthood (e.g., } \\
\text { violence) }\end{array}$ & $\begin{array}{l}\text { Age, ethnicity, housing } \\
\text { status, marital status, } \\
\text { acculturation, parenting } \\
\text { status, parent substance } \\
\text { abuse, foster care status, } \\
\text { number and age of } \\
\text { children, income, } \\
\text { psychological factors } \\
\text { (coping and parental } \\
\text { hassles), social service } \\
\text { utilization, social network } \\
\text { size }\end{array}$ & $\begin{array}{l}\text { Exploratory analytic approach } \\
\text { identified factors } \\
\text { differentiating families with } \\
\text { child hunger from those with } \\
\text { no hunger, these did not } \\
\text { include the mental health } \\
\text { factors. Multivariable analyses: } \\
\text { The experience of sexual abuse } \\
\text { in childhood increased the } \\
\text { odds of adult hunger (aOR: } \\
4.23,95 \% \text { CI } 2.28-7.82) ; \\
\text { intimate partner violence in } \\
\text { adulthood and a PTSD } \\
\text { diagnosis appeared to be } \\
\text { mediators of the childhood } \\
\text { sexual abuse-current hunger } \\
\text { association. Financial support } \\
\text { from a sibling reduced the } \\
\text { odds of experiencing food } \\
\text { insecurity. }\end{array}$ \\
\hline \multicolumn{9}{|c|}{ NHANES-III food insufficiency indicators } \\
\hline \multicolumn{9}{|c|}{ Longitudinal analyses } \\
\hline $\begin{array}{l}\text { Heflin et al. } \\
2005 \text { [62] }\end{array}$ & $\begin{array}{l}\text { Mothers (18-54 years) } \\
\text { receiving public } \\
\text { assistance in urban } \\
\text { Michigan, US, included } \\
\text { African American, } \\
\text { non-Hispanic White } \\
\text { races/ethnicities } \\
\text { Women's Employment } \\
\text { Study }\end{array}$ & $\begin{array}{l}\text { Longitudinal } \\
\text { (753) }\end{array}$ & $\begin{array}{l}\text { Examine effect of food } \\
\text { insecurity on the mental } \\
\text { health status of welfare } \\
\text { recipients over a 3-year } \\
\text { period }\end{array}$ & $\begin{array}{l}\text { NHANES-III } \\
\text { food } \\
\text { insufficiency } \\
\text { question } \\
\text { Authors noted } \\
\text { that this } \\
\text { measure is } \\
\text { widely accepted } \\
\text { as a valid } \\
\text { measure of food } \\
\text { insufficiency }\end{array}$ & $\begin{array}{l}\text { CIDI short form, } \\
\text { Pearlin Mastery } \\
\text { Scale } 7 \text { item }\end{array}$ & $\begin{array}{l}\text { Clinical diagnosis } \\
\text { of depression, } \\
\text { mastery (degree } \\
\text { to which } \\
\text { individuals } \\
\text { perceive } \\
\text { themselves to be } \\
\text { in control of their } \\
\text { own lives) }\end{array}$ & $\begin{array}{l}\text { Household size, marital } \\
\text { status, household income, } \\
\text { poverty-related stressful } \\
\text { life circumstances, } \\
\text { neighborhood hazards, } \\
\text { domestic violence, } \\
\text { experiences of } \\
\text { discrimination based on } \\
\text { race and gender }\end{array}$ & $\begin{array}{l}\text { Multivariable fixed effects } \\
\text { models: Changes in food } \\
\text { insecurity significantly predict } \\
\text { changes in major depression } \\
\text { status after adjusting for } \\
\text { changes in household } \\
\text { composition and } \\
\text { socio-environmental stressors } \\
(\beta=0.75, \text { SE } 0.24 . p<0.01) \text {. No } \\
\text { association observed between } \\
\text { changes in food insufficiency } \\
\text { status and changes in mastery. }\end{array}$ \\
\hline
\end{tabular}


Table A1. Cont.

\begin{tabular}{|c|c|c|c|c|c|c|c|c|}
\hline Reference & $\begin{array}{l}\text { Sample (Participants } \\
\text { (Age), Setting, } \\
\text { Race/Ethnicity, Data } \\
\text { Source) }\end{array}$ & $\begin{array}{l}\text { Study Design } \\
\text { (Sample Size) }\end{array}$ & Purpose & $\begin{array}{l}\text { Food Security } \\
\text { Measure }\end{array}$ & $\begin{array}{l}\text { Mental Health } \\
\text { Measure }\end{array}$ & $\begin{array}{c}\text { Mental Health } \\
\text { States/Conditions }\end{array}$ & Covariates Considered & $\begin{array}{l}\text { Analytic Approach and Key } \\
\text { Findings }\end{array}$ \\
\hline \multicolumn{9}{|c|}{ Cross-sectional analyses } \\
\hline $\begin{array}{l}\text { Siefert et al. } \\
2001[64]\end{array}$ & $\begin{array}{l}\text { Single women receiving } \\
\text { welfare (mean age, } \\
28 \text { years) living in } \\
\text { urban Michigan, US, } \\
\text { included } \\
\text { African-American, } \\
\text { White women } \\
\text { Women's Employment } \\
\text { Study }\end{array}$ & $\begin{array}{l}\text { Cross-sectional } \\
(724)\end{array}$ & $\begin{array}{l}\text { Examine relationship } \\
\text { between food } \\
\text { insufficiency and } \\
\text { physical and mental } \\
\text { health among } \\
\text { low-income women }\end{array}$ & $\begin{array}{l}\text { NHANES-III } \\
\text { food } \\
\text { insufficiency } \\
\text { question } \\
\text { Authors noted } \\
\text { that this } \\
\text { measure is } \\
\text { widely accepted } \\
\text { as a valid } \\
\text { measure of food } \\
\text { insufficiency }\end{array}$ & $\begin{array}{l}\text { CIDI short form } \\
\text { Authors noted } \\
\text { that acceptable } \\
\text { test-retest } \\
\text { reliability and } \\
\text { clinical validity } \\
\text { have been } \\
\text { observed }\end{array}$ & $\begin{array}{l}\text { Clinical diagnosis } \\
\text { of major } \\
\text { depressive } \\
\text { disorder and } \\
\text { generalized } \\
\text { anxiety disorder }\end{array}$ & $\begin{array}{l}\text { Self-rated health, physical } \\
\text { limitations, age, number of } \\
\text { children in the household, } \\
\text { education level, poverty } \\
\text { level, employment, } \\
\text { poverty-related stressful } \\
\text { life events and conditions }\end{array}$ & $\begin{array}{l}\text { Multivariable analyses: Food } \\
\text { insufficiency significantly } \\
\text { predicted major depressive } \\
\text { disorder (aOR } 2.21,95 \% \text { CI } \\
1.48-3.29) \text {. The association } \\
\text { between food insufficiency and } \\
\text { generalized anxiety disorder, } \\
\text { adjusted for covariates, was } \\
\text { not significant. }\end{array}$ \\
\hline $\begin{array}{l}\text { Siefert et al. } \\
2007 \text { [63] }\end{array}$ & $\begin{array}{l}\text { African-American } \\
\text { mothers (mean age, } \\
28 \text { years) recruited from } \\
39 \text { high-poverty census } \\
\text { areas in Detroit, US } \\
\text { Detroit Center for } \\
\text { Research on Oral } \\
\text { Health Disparities }\end{array}$ & $\begin{array}{l}\text { Cross-sectional } \\
\text { (multiple waves } \\
\text { of data } \\
\text { collection, } \\
\text { relevant } \\
\text { variables were } \\
\text { assessed in } \\
\text { wave 1) (824) }\end{array}$ & $\begin{array}{l}\text { Determine correlates of } \\
\text { depressive symptoms } \\
\text { among low-income } \\
\text { mothers }\end{array}$ & $\begin{array}{l}\text { NHANES-III } \\
\text { food } \\
\text { insufficiency } \\
\text { questionAuthors } \\
\text { noted that this } \\
\text { measure is } \\
\text { widely accepted } \\
\text { as a valid } \\
\text { measure of food } \\
\text { insufficiency }\end{array}$ & $\begin{array}{l}\text { CES-D, 20-item } \\
\text { Authors noted } \\
\text { that the CES-D } \\
\text { is a reliable and } \\
\text { well-validated } \\
\text { sale, with } \\
\text { standard } \\
\text { scoring widely } \\
\text { used in research, } \\
\text { four-factor } \\
\text { structure found } \\
\text { in the general } \\
\text { population has } \\
\text { also been found } \\
\text { in } \\
\text { African-Americans } \\
\text { with low } \\
\text { socioeconomic } \\
\text { status }\end{array}$ & $\begin{array}{l}\text { Depressive } \\
\text { symptoms }\end{array}$ & $\begin{array}{l}\text { Living in poorly } \\
\text { maintained housing, not } \\
\text { being employed, } \\
\text { experiences of everyday } \\
\text { discrimination, } \\
\text { instrumental and } \\
\text { emotional social support, } \\
\text { age, education, household } \\
\text { size, number of children } \\
<18 \text { years of age, income }\end{array}$ & $\begin{array}{l}\text { Bivariate analyses: Mothers } \\
\text { with depressive symptoms } \\
\text { more likely to report } \\
\text { household food insufficiency } \\
(14.5 \%) \text { compared to women } \\
\text { without depressive symptoms } \\
(6 \%) \text {. Multivariable analyses: } \\
\text { In models adjusted for income } \\
\text { and education, living in a } \\
\text { food-insufficient household } \\
\text { was associated with } 2.5 \text { greater } \\
\text { odds ( } 95 \% \text { CI } 1.25-4.98) \text { of } \\
\text { maternal depressive symptoms. } \\
\text { Instrumental social support } \\
\text { was a protective factor. }\end{array}$ \\
\hline \multicolumn{9}{|c|}{ Other brief measures } \\
\hline \multicolumn{9}{|c|}{ Cross-sectional analyses } \\
\hline $\begin{array}{l}\text { Birmingham et al. } \\
2011 \text { [42] }\end{array}$ & $\begin{array}{l}\text { Mothers of newborns } \\
\text { (mean age, 25 years), } \\
\text { US., included African } \\
\text { American, Hispanic, } \\
\text { White, Asian, other } \\
\text { races/ethnicities, } \\
\text { recruited from urban } \\
\text { pediatric emergency } \\
\text { departments }\end{array}$ & $\begin{array}{l}\text { Cross-sectional } \\
\text { (195) }\end{array}$ & $\begin{array}{l}\text { To examine the } \\
\text { performance of the } \\
\text { Edinburgh Postpartum } \\
\text { Depression Scale (EPDS) } \\
\text { for screening patients in } \\
\text { emergency departments, } \\
\text { and examine correlates of } \\
\text { postpartum depression }\end{array}$ & $\begin{array}{l}2 \text { items } \\
\text { querying worry } \\
\text { about the food } \\
\text { supply and } \\
\text { inability to eat } \\
\text { the way you } \\
\text { should due to } \\
\text { lack of money }\end{array}$ & $\begin{array}{l}\text { EPDS 3-item } \\
\text { short form }\end{array}$ & $\begin{array}{l}\text { Postpartum } \\
\text { depressive } \\
\text { symptoms }\end{array}$ & $\begin{array}{l}\text { Maternal age, ethnicity, } \\
\text { education, marital status, } \\
\text { employment, maternal } \\
\text { health problems, health } \\
\text { insurance, household } \\
\text { income, household size, } \\
\text { father's presence in the } \\
\text { home, social support, } \\
\text { infant health and health } \\
\text { insurance, }\end{array}$ & $\begin{array}{l}\text { Multivariable analyses: Having } \\
\text { concerns about food increased } \\
\text { odds (aOR 5.5, 95\% CI 2.2-13.5) } \\
\text { of postpartum depression. }\end{array}$ \\
\hline
\end{tabular}


Table A1. Cont.

\begin{tabular}{|c|c|c|c|c|c|c|c|c|}
\hline Reference & $\begin{array}{c}\text { Sample (Participants } \\
\text { (Age), Setting, } \\
\text { Race/Ethnicity, Data } \\
\text { Source) }\end{array}$ & $\begin{array}{l}\text { Study Design } \\
\text { (Sample Size) }\end{array}$ & Purpose & $\begin{array}{l}\text { Food Security } \\
\text { Measure }\end{array}$ & $\begin{array}{l}\text { Mental Health } \\
\text { Measure }\end{array}$ & $\begin{array}{l}\text { Mental Health } \\
\text { States/Conditions }\end{array}$ & Covariates Considered & $\begin{array}{l}\text { Analytic Approach and } \\
\text { Key Findings }\end{array}$ \\
\hline $\begin{array}{l}\text { Carter et al. } \\
2011[43]\end{array}$ & $\begin{array}{l}\text { General population } \\
\text { (15+ years) in New } \\
\text { Zealand, included } \\
\text { NZ/European, Maori, } \\
\text { Pacific, Asian, and } \\
\text { other groups. } \\
\text { New Zealand Survey of } \\
\text { Families, Income, and } \\
\text { Employment, } \\
\text { 2002-2010 }\end{array}$ & $\begin{array}{l}\text { Cross-sectional } \\
(18,090)\end{array}$ & $\begin{array}{l}\text { Examine association } \\
\text { between food insecurity } \\
\text { and psychological } \\
\text { distress }\end{array}$ & $\begin{array}{l}\text { Food security items } \\
\text { from measure of } \\
\text { individual } \\
\text { deprivation } \\
\text { (NZiDep): } 3 \text { items } \\
\text { querying use of food } \\
\text { banks and food } \\
\text { compromises due to } \\
\text { lack of money for } \\
\text { food in last } 12 \text { months }\end{array}$ & Kessler-10 scale & $\begin{array}{l}\text { Symptoms of } \\
\text { psychological } \\
\text { distress }\end{array}$ & $\begin{array}{l}\text { Age, ethnicity, legal marital } \\
\text { status, family composition, } \\
\text { household income, } \\
\text { employment, highest level } \\
\text { of education, } \\
\text { individual-level } \\
\text { deprivation }\end{array}$ & $\begin{array}{l}\text { Multivariable analyses: } \\
\text { Women who experienced } \\
\text { food insecurity were } \\
\text { more likely to report } \\
\text { moderate to high levels } \\
\text { of psychological distress } \\
\text { (OR 2.1, 95\% CI 1.8-2.4). }\end{array}$ \\
\hline $\begin{array}{l}\text { Klesges et al. } \\
2001 \text { [68] }\end{array}$ & $\begin{array}{l}\text { Disabled women }(65+ \\
\text { years) living in the } \\
\text { community in } \\
\text { Baltimore, US, } \\
\text { primarily White } \\
\text { women } \\
\text { Women's Health and } \\
\text { Aging Study }\end{array}$ & $\begin{array}{l}\text { Cross-sectional } \\
(1001)\end{array}$ & $\begin{array}{l}\text { Examine prevalence and } \\
\text { correlates of financial } \\
\text { difficulty acquiring food }\end{array}$ & $\begin{array}{l}\text { Single item, } \\
\text { self-perception of } \\
\text { food sufficiency } \\
\text { "How often does it } \\
\text { happen that you (and } \\
\text { your husband) do not } \\
\text { have enough money } \\
\text { to afford the kind of } \\
\text { food you should } \\
\text { have?" } \\
\text { Authors note that } \\
\text { such single-item } \\
\text { measures have shown } \\
\text { validity in } \\
\text { discriminating energy } \\
\text { intake differences, but } \\
\text { have poor sensitivity } \\
\text { and underestimate } \\
\text { prevalence }\end{array}$ & $\begin{array}{l}\text { Geriatric } \\
\text { Depression } \\
\text { Scale } \\
\text { (GDS),Hopkins } \\
\text { Symptom } \\
\text { Checklist } \\
\text { subscale for } \\
\text { anxiety, 20-item } \\
\text { perceived } \\
\text { quality of life } \\
\text { scale }\end{array}$ & $\begin{array}{l}\text { Symptoms of } \\
\text { depression, } \\
\text { anxiety, quality of } \\
\text { life }\end{array}$ & $\begin{array}{l}\text { Age, marital status, and } \\
\text { number of household } \\
\text { members }\end{array}$ & $\begin{array}{l}\text { Multivariable analyses: } \\
\text { In non-white women, } \\
\text { depression was } \\
\text { associated with financial } \\
\text { difficulty accessing food } \\
\text { (aOR } 1.13,95 \% \text { CI } \\
1.04-1.22) \text {. This } \\
\text { association not significant } \\
\text { among white women } \\
\text { after adjusting for } \\
\text { covariates. }\end{array}$ \\
\hline $\begin{array}{l}\text { Sharkey et al. } \\
2003 \text { [69] }\end{array}$ & $\begin{array}{l}\text { Women (60+ years) } \\
\text { who are homebound } \\
\text { (as a result of disability, } \\
\text { illness, or isolation), } \\
\text { recruited from meal } \\
\text { delivery programs in } \\
\text { North Carolina, US, } \\
\text { included } \\
\text { African-American and } \\
\text { White women } \\
\text { Nutrition and Function } \\
\text { Study (NAFS) }\end{array}$ & $\begin{array}{l}\text { Cross-sectional } \\
(279)\end{array}$ & $\begin{array}{l}\text { Examine food sufficiency } \\
\text { and association with } \\
\text { dietary intake and } \\
\text { burden of multiple } \\
\text { diseases }\end{array}$ & $\begin{array}{l}\text { Four items adapted } \\
\text { from a national } \\
\text { nutrition evaluation } \\
\text { survey, } 2 \text { situations } \\
\text { related to lack of food, } \\
2 \text { related to making } \\
\text { trade-offs between } \\
\text { food and other } \\
\text { necessities } \\
\text { Authors noted that } \\
\text { the items were } \\
\text { previously used in a } \\
\text { national evaluation of } \\
\text { elderly nutrition } \\
\text { programs }\end{array}$ & $\begin{array}{l}\text { Geriatric } \\
\text { Depression } \\
\text { Scale (GDS) } \\
\text { 15-item short } \\
\text { form }\end{array}$ & $\begin{array}{l}\text { Depressive } \\
\text { symptoms }\end{array}$ & Not applicable & $\begin{array}{l}\text { Bivariate analyses: } \\
\text { Women experiencing } \\
\text { food insufficiency had } \\
\text { higher prevalence of } 6 \text { or } \\
\text { more depressive } \\
\text { symptoms ( } 52 \% \text { vs. } 26 \% \text {, } \\
p=0.03 \text { ) and disease } \\
\text { multi-morbidity }(74 \% \text { vs. } \\
41 \%, p<0.001 \text { ) compared } \\
\text { to those who were food } \\
\text { sufficient. }\end{array}$ \\
\hline
\end{tabular}




\section{References}

1. Gregory, C.A.; Coleman-Jensen, A. Food Insecurity, Chronic Disease, and Health among Working-Age Adults; Economic Research Report, 235; U.S. Department of Agriculture, Economic Research Service: Washington, DC, USA, 2017. Available online: https://www.ers.usda.gov/webdocs/publications/84467/err-235_ summary.pdf? v=42942 (accessed on 27 June 2018).

2. Tarasuk, V.; Mitchell, A.; Dachner, N. Household Food Insecurity in Canada, 2014. 2016. Available online: http:/ / proof.utoronto.ca/resources/proof-annual-reports/annual-report-2014/ (accessed on 27 June 2018).

3. Coleman-Jensen, A.; Rabbitt, M.P.; Gregory, C.; Singh, A. Household Food Security in the United States in 2016; Economic Research Report; United States Department of Agriculture: Washington, DC, USA, 2017. Available online: https: / / www.ers.usda.gov / webdocs / publications / 84973/err237_summary.pdf?v=42979 (accessed on 27 June 2018).

4. Tarasuk, V.; Mitchell, A.; Dashner, N. Household Food Insecurity in Canada, 2012. 2014. Available online: http:/ / proof.utoronto.ca/resources/proof-annual-reports/annual-report-2012/ (accessed on 27 June 2018).

5. Bates, B.; Roberts, C.; Lepps, H.; Porter, L. The Food \& You Survey: Wave 4. 2017. Available online: https: / / www.food.gov.uk/sites/default/files/media/document/food-and-you-w4-exec-summary.pdf (accessed on 27 June 2018).

6. Lindberg, R.; Lawrence, M.; Gold, L.; Friel, S.; Pegram, O. Food insecurity in Australia: Implications for general practitioners. Aust. Fam. Physician 2015, 44, 859-863. [PubMed]

7. FAO. Agriculture and Development Economics Division. Food Security: Policy Brief. 2006. Available online: http:/ / www.fao.org/fileadmin/templates/faoitaly/documents / pdf/pdf_Food_Security_Cocept_ Note.pdf (accessed on 27 June 2018).

8. Bickel, G.; Nord, M.; Price, C.; Hamilton, W.; Cook, J. Guide to Measuring Household Food Security; USDA: Alexandria, VA, USA, 2000. Available online: https:/ / fns-prod.azureedge.net/sites/default/files/FSGuide. pdf (accessed on 27 June 2018).

9. Entmacher, J.; Robbins, K.; Vogtman, J.; Morrison, A. Insecure and Unequal: Poverty and Income among Women and Families, 2000-2013; National Women's Law Center: Washington, DC, USA, 2014; Available online: https:/ / nwlc.org/resources/insecure-unequal-poverty-and-income-among-women-and-families2000-2013/ (accessed on 27 June 2018).

10. Maheux, H.; Chui, T. Women in Canada: A Gender-Based Statistical Report; Statistics: Ottawa, ON, Canada, 2011; Available online: https:/ / www150.statcan.gc.ca/n1/pub/89-503-x/89-503-x2010001-eng.htm (accessed on 27 June 2018).

11. Semega, J.L.; Fontenot, K.R.; Kollar, M.A. Income and Poverty in the United States: 2016. Current Population Reports; 2017. Available online: https:/ /www.census.gov/library/publications/2017/demo/p60-259.html (accessed on 27 June 2018).

12. Ivers, L.C.; Cullen, K.A. Food insecurity: Special considerations for women. Am. J. Clin. Nutr. 2011, 94, 1740S-1744S. [CrossRef] [PubMed]

13. Knowles, M.; Rabinowich, J.; Ettinger de Cuba, S.; Cutts, D.B.; Chilton, M. "Do you wanna breathe or eat?": Parent perspectives on child health consequences of food insecurity, trade-offs, and toxic stress. Matern. Child Health J. 2015, 20, 25-32. [CrossRef] [PubMed]

14. Kirkpatrick, S.I.; Tarasuk, V. Food insecurity is associated with nutrient inadequacies among Canadian adults and adolescents. J. Nutr. 2008, 138, 604-612. [CrossRef] [PubMed]

15. Hanson, K.L.; Olson, C.M. Chronic health conditions and depressive symptoms strongly predict persistent food insecurity among rural low-income families. J. Health Care Poor Underserved. 2012, 23, 1174-1188. [CrossRef] [PubMed]

16. Tarasuk, V.; Mitchell, A.; McLaren, L.; McIntyre, L. Chronic physical and mental health conditions among adults may increase vulnerability to household food insecurity. J. Nutr. 2013, 143, 1785-1793. [CrossRef] [PubMed]

17. Martin, M.S.; Maddocks, E.; Chen, Y.; Gilman, S.E.; Colman, I. Food insecurity and mental illness: Disproportionate impacts in the context of perceived stress and social isolation. Public Health 2016, 132, 86-91. [CrossRef] [PubMed] 
18. McIntyre, L.; Williams, J.V.A.; Lavorato, D.H.; Patten, S. Depression and suicide ideation in late adolescence and early adulthood are an outcome of child hunger. J. Affect. Disord. 2013, 150, 123-129. [CrossRef] [PubMed]

19. Jessiman-Perreault, G.; McIntyre, L. The household food insecurity gradient and potential reductions in adverse population mental health outcomes in Canadian adults. SSM Popul. Health 2017, 3, 464-472. [CrossRef] [PubMed]

20. Davison, K.M.; Marshall-Fabien, G.L.; Tecson, A. Association of moderate and severe food insecurity with suicidal ideation in adults: National survey data from three Canadian provinces. Soc. Psychiatry Psychiatr. Epidemiol. 2015, 50, 963-972. [CrossRef] [PubMed]

21. Health Canada. Canadian Community Health Survey, Cycle 2.2, Nutrition (2004): Income-related Household Food Security in Canada; No. 4696; HC Publisher: Ottawa, ON, Canada, 2007; Available online: https:/ / www.canada.ca/content/dam/hc-sc/migration/hc-sc/fn-an/alt_formats/hpfb-dgpsa/ pdf/surveill/income_food_sec-sec_alim-eng.pdf (accessed on 27 June 2018).

22. Arksey, H.; O’Malley, L. Scoping studies: Towards a methodological framework. Int. J. Soc. Res. Methodol. 2005, 8, 19-32. [CrossRef]

23. Moher, D.; Liberati, A.; Tetzlaff, J.; Altman, D.G.; Grp, P. Preferred reporting items for systematic reviews and meta-analyses: The PRISMA statement (reprinted from annals of internal medicine). Phys. Ther. 2009, 89, 873-880. [PubMed]

24. Corman, H.; Curtis, M.A.; Noonan, K.; Reichman, N.E. Maternal depression as a risk factor for children's inadequate housing conditions. Soc. Sci. Med. 2016, 149, 76-83. [CrossRef] [PubMed]

25. Garg, A.; Toy, S.; Tripodis, Y.; Cook, J.; Cordella, N. Influence of maternal depression on household food insecurity for low-income families. Acad Pediatr. 2015, 15, 305-310. [CrossRef] [PubMed]

26. Hernandez, D.C.; Marshall, A.; Mineo, C. Maternal depression mediates the association between intimate partner violence and food insecurity. J. Womens Health 2014, 23, 29-37. [CrossRef] [PubMed]

27. Laraia, B.; Vinikoor-Imler, L.C.; Siega-Riz, A.M. Food insecurity during pregnancy leads to stress, disordered eating, and greater postpartum weight among overweight women. Obesity 2015, 23, 1303-1311. [CrossRef] [PubMed]

28. Chilton, M.M.; Rabinowich, J.R.; Woolf, N.H. Very low food security in the USA is linked with exposure to violence. Public Health Nutr. 2013, 17, 1-10. [CrossRef] [PubMed]

29. McCurdy, K.; Kisler, T.; Gorman, K.S.; Metallinos-Katsaras, E. Food- and health-related correlates of self-reported body mass index among low-income mothers of young children. J. Nutr. Educ. Behav. 2015, 47, 225-233. [CrossRef] [PubMed]

30. Sun, J.; Knowles, M.; Patel, F.; Frank, D.A.; Heeren, T.C.; Chilton, M. Childhood adversity and adult reports of food insecurity among households with children. Am. J. Prev. Med. 2016, 50, 561-572. [CrossRef] [PubMed]

31. Trapp, C.M.; Burke, G.; Gorin, A.A.; Wiley, J.F.; Hernandez, D.; Crowell, R.E.; Grant, A.; Beaulieu, A.; Cloutier, M.M. The relationship between dietary patterns, body mass index percentile, and household food security in young urban children. Child. Obes. 2015, 11, 148-155. [CrossRef] [PubMed]

32. Muldoon, K.A.; Duff, P.K.; Fielden, S.; Anema, A. Food insufficiency is associated with psychiatric morbidity in a nationally representative study of mental illness among food insecure Canadians. Soc. Psychiatry Psychiatr. Epidemiol. 2013, 48, 795-803. [CrossRef] [PubMed]

33. Sidebottom, A.C.; Hellerstedt, W.L.; Harrison, P.A.; Hennrikus, D. An examination of prenatal and postpartum depressive symptoms among women served by urban community health centers. Arch. Womens Ment. Health 2014, 17, 27-40. [CrossRef] [PubMed]

34. Mathews, L.; Morris, M.N.; Schneider, J.; Goto, K. The relationship between food security and poor health among female WIC participants. J. Hunger Environ. Nutr. 2010, 5, 85-99. [CrossRef]

35. Ajrouch, K.J.; Reisine, S.; Lim, S.; Sohn, W.; Ismail, A. Situational stressors among African-American women living in low-income urban areas: The role of social support. Women Health 2010, 50, 159-175. [CrossRef] [PubMed]

36. Hromi-Fiedler, A.; Bermúdez-Millán, A.; Segura-Pérez, S.; Pérez-Escamilla, R. Household food insecurity is associated with depressive symptoms among low-income pregnant Latinas. Matern. Child Nutr. 2011, 7, 421-430. [CrossRef] [PubMed]

37. Dressler, H.; Smith, C. Depression affects emotional eating and dietary intake and is related to food insecurity in a group of multiethnic, low-income women. J. Hunger Environ. Nutr. 2015, 10, 496-510. [CrossRef] 
38. Peterman, J.N.; Wilde, P.E.; Silka, L.; Bermudez, O.I.; Rogers, B.L. Food insecurity among Cambodian refugee women two decades post resettlement. J. Immigr. Minor. Health 2013, 15, 372-380. [CrossRef] [PubMed]

39. Sharpe, P.A.; Whitaker, K.; Alia, K.A.; Wilcox, S.; Hutto, B. Dietary intake, behaviors and psychosocial factors among women from food-secure and food-insecure households in the United States. Ethn Dis. 2016, 26, 139-146. [CrossRef] [PubMed]

40. Davey-Rothwell, M.A.; Flamm, L.J.; Kassa, H.T.; Latkin, C.A. Food insecurity and depressive symptoms: Comparison of drug using and nondrug-using women at risk for HIV. J. Commun. Psychol. 2014, 42, 469-478. [CrossRef] [PubMed]

41. Sharkey, J.R.; Johnson, C.M.; Dean, W.R. Relationship of household food insecurity to health-related quality of life in a large sample of rural and urban women. Women Health 2011, 51, 442-460. [CrossRef] [PubMed]

42. Birmingham, M.C.; Chou, K.J.; Crain, E.F. Screening for postpartum depression in pediatric emergency department. Pediatr. Emerg. Care 2011, 27, 795-800. [CrossRef] [PubMed]

43. Carter, K.N.; Kruse, K.; Blakely, T.; Collings, S. The association of food security with psychological distress in New Zealand and any gender differences. Soc. Sci. Med. 2011, 72, 1463-1471. [CrossRef] [PubMed]

44. Melchior, M.; Caspi, A.; Howard, L.M.; Ambler, A.P.; Bolton, H.; Mountain, N.; Moffitt, T.E. Mental health context of food insecurity: A representative cohort of families with young children. Pediatrics 2009, 124, e564-e572. [CrossRef] [PubMed]

45. Lent, M.D.; Petrovic, L.E.; Swanson, J.A.; Olson, C.M. Maternal mental health and the persistence of food insecurity in poor rural families. J. Health Care Poor Underserved. 2009, 20, 645-661. [CrossRef] [PubMed]

46. Wunderlich, G.S.; Norwood, J. Food Insecurity and Hunger in the United States: An Assessment of the Measure; National Academies Press: Washington, DC, USA, 2006; Available online: https:/ / www.nap.edu/catalog/ 11578/food-insecurity-and-hunger-in-the-united-states-an-assessment (accessed on 27 June 2018).

47. Radimer, K.L.; Olson, C.M.; Greene, J.C.; Campbell, C.C.; Habicht, J.P. Understanding hunger and developing indicators to assess it in women and children. J. Nutr. Educ. 1992, 24, 36S-44S. [CrossRef]

48. Wehler, C.A.; Scott, R.I.; Anderson, J. The community child hunger identification project: A model of domestic hunger-Demonstration project in Seattle, Washington. J. Nutr. Educ. 1992, 24 (Suppl. 1), $29 \mathrm{~S}-35 \mathrm{~S}$.

49. Frongillo, E.A., Jr.; Rauschenbach, B.S.; Olson, C.M.; Kendall, A.; Colmenares, A.G. Questionnaire-based measures are valid for the identification of rural households with hunger and food insecurity. J. Nutr. 1997, 127, 699-705. [CrossRef] [PubMed]

50. Briefel, R.R.; Woteki, C. Development of food sufficiency questions for the third national health and nutrition examination survey. J. Nutr. Educ. 1992, 24 (Suppl. 1), 24S-28S. [CrossRef]

51. Tarasuk, V. Discussion Paper on Household and Individual Food Insecurity. 2001. Available online: https:/ / www.canada.ca/en/health-canada/services/food-nutrition/healthy-eating/nutrition-policyreports / discussion-paper-household-individual-food-insecurity-2001.html (accessed on 27 June 2018).

52. Wehler, C.; Weinreb, L.F.; Huntington, N.; Scott, R. Risk and protective factors for adult and child hunger among low-income housed and homeless female-headed families. Am. J. Public Health 2004, 94, 109-115. [CrossRef] [PubMed]

53. Bronte-Tinkew, J.; Zaslow, M.; Capps, R.; Horowitz, A.; McNamara, M. Food insecurity works through depression, parenting, and infant feeding to influence overweight and health in toddlers. J. Nutr. 2007, 137, 2160-2165. [CrossRef] [PubMed]

54. Casey, P.; Goolsby, S.; Berkowitz, C.; Frank, D.; Cook, J.; Cutts, D.; Black, M.M.; Zaldivar, N.; Levenson, S.; Heeren, T.; et al. Maternal depression, changing public assistance, food security, and child health status. Pediatrics 2004, 113, 298-304. [CrossRef] [PubMed]

55. Huddleston-Casas, C.; Charnigo, R.; Simmons, L.A. Food insecurity and maternal depression in rural, low-income families: A longitudinal investigation. Public Health Nutr. 2009, 12, 1133-1140. [CrossRef] [PubMed]

56. Laraia, B.A.; Siega-Riz, A.M.; Gundersen, C.; Dole, N. Psychosocial factors and socioeconomic indicators are associated with household food insecurity among pregnant women. J. Nutr. 2006, 136, 177-182. [CrossRef] [PubMed]

57. Kaiser, L.; Baumrind, N.; Dumbauld, S. Who is food-insecure in California? Findings from the California Women's Health Survey, 2004. Public Health Nutr. 2007, 10, 574-581. [CrossRef] [PubMed] 
58. Laraia, B.A.; Borja, J.B.; Bentley, M.E. Grandmothers, fathers, and depressive symptoms are associated with food insecurity among low-income first-time African-American mothers in North Carolina. J. Am. Diet. Assoc. 2009, 109, 1042-1047. [CrossRef] [PubMed]

59. Whitaker, R.C.; Phillips, S.M.; Orzol, S.M. Food insecurity and the risks of depression and anxiety in mothers and behavior problems in their preschool-aged children. Pediatrics 2006, 118, e859-e868. [CrossRef] [PubMed]

60. Harrison, P.A.; Sidebottom, A.C. Systematic prenatal screening for psychosocial risks. J. Health Care Poor Underserved. 2008, 19, 258-276. [CrossRef] [PubMed]

61. United States Centers for Disease Control and Prevention. Third National Health and Nutrition Examination Survey (NHANES III), 1988-94: NHANES-III Household Adult Data File Documentation, Ages 17+. Available online: https:/ / wwwn.cdc.gov/nchs/nhanes/nhanes3/DataFiles.aspx (accessed on 27 June 2018).

62. Heflin, C.M.; Siefert, K.; Williams, D.R. Food insufficiency and women's mental health: Findings from a 3-year panel of welfare recipients. Soc. Sci. Med. 2005, 61, 1971-1982. [CrossRef] [PubMed]

63. Siefert, K.; Finlayson, T.L.; Williams, D.R.; Delva, J.; Ismail, A.I. Modifiable risk and protective factors for depressive symptoms in low-income African American mothers. Am. J. Orthopsychiatr. 2007, 77, 113-123. [CrossRef] [PubMed]

64. Siefert, K.; Heflin, C.M.; Corcoran, M.E.; Williams, D.R. Food insufficiency and the physical and mental health of low-income women. Women Health 2001, 32, 159-177. [CrossRef] [PubMed]

65. Salmond, C.; Crampton, P.; King, P.; Waldegrave, C. NZiDep: A New Zealand index of socioeconomic deprivation for individuals. Soc. Sci. Med. 2006, 62, 1474-1485. [CrossRef] [PubMed]

66. Kendall, A.; Olson, C.; Frongillo, E.A., Jr. Validation of the Radimer/Cornell measures of hunger and food insecurity. J. Nutr. 1995, 125, 2793-2801. [PubMed]

67. Hamelin, A.M.; Beaudry, M.; Habicht, J.P. Characterization of household food insecurity in Québec: Food and feelings. Soc. Sci. Med. 2002, 54, 119-132. [CrossRef]

68. Klesges, L.M.; Pahor, M.; Guralnik, J.M.; Shorr, R.I.; Williamson, J.D. Financial difficulty acquiring food among elderly disabled women: Results from the Women's Health and Aging Study (WHAS). Am. J. Public Health 2001, 91, 68-75. [PubMed]

69. Sharkey, J.R. Risk and presence of food insufficiency are associated with low nutrient intakes and multimorbidity among homebound older women who receive home-delivered meals. J. Nutr. 2003, 133, 3485-3491. [CrossRef] [PubMed]

70. World Health Organization. WHO WMH-CIDI Instruments. World Health Organization. 2018. Available online: https: / / www.hcp.med.harvard.edu/wmhcidi/about-the-who-wmh-cidi/ (accessed on 27 June 2018).

71. Radloff, L.S. The CES-D scale: A self-report depression scale for research in the general population. Appl. Psychol. Meas. 1977, 1, 385-401. [CrossRef]

72. American Psychological Association. The State-Trait Anxiety Inventory (STAI). 2018. Available online: http://www.apa.org/pi/about/publications/caregivers/practice-settings/assessment/tools/traitstate.aspx (accessed on 27 June 2018).

73. Derogatis, L.R.; Lipman, R.S.; Rickels, K.; Uhlenhuth, E.H.; Covi, L. The Hopkins Symptom Checklist (HSCL): A self-report symptom inventory. Behav. Sci. 1974, 19,1-15. [CrossRef] [PubMed]

74. Kemper, K.J.; Babonis, T.R. Screening for maternal depression in pediatric clinics. Am. J. Dis. Child. 1992, 146, 876-878. [CrossRef] [PubMed]

75. Cox, J.L.; Holden, J.M.; Sagovsky, R. Detection of postnatal depression: Development of the 10-item Edinburgh Postnatal Depression Scale. Br. J. Psychiatry 1987, 150, 782-786. [CrossRef] [PubMed]

76. Yesavage, J.A.; Brink, T.L.; Rose, T.L.; Lum, O.; Huang, V.; Adey, M.; Leirer, V.O. Development and validation of a geriatric depression screening scale: A preliminary report. J. Psychiatr. Res. 1982, 17, 37-49. [CrossRef]

77. Cohen, S.; Kamarck, T.; Mermelstein, R. A global measure of perceived stress. J. Health Soc. Behav. 1983, 24, 385-396. [CrossRef] [PubMed]

78. Weiner, I.B.; Craighead, W.E. Diagnostic Interview Schedule for DSM-IV (DIS-IV). In The Corsini Encyclopedia of Psychology; John Wiley \& Sons Inc.: Hoboken, NJ, USA, 2009.

79. Andrews, G.; Slade, T. Interpreting scores on the Kessler Psychological Distress Scale (K10). Aust. N. Z. J. Public Health 2010, 25, 494-497. [CrossRef]

80. Kroenke, K.; Spitzer, R.L.; Williams, J.B.W. The PHQ-9: Validity of a brief depression severity measure. J. Gen. Intern. Med. 2001, 16, 606-613. [CrossRef] [PubMed] 
81. Pearlin, L.I.; Menaghan, E.G.; Lieberman, M.A.; Mullan, J.T. The stress process. J. Health Soc. Behav. 1981, 22, 337-356. [CrossRef] [PubMed]

82. Rosenberg, M. Society and the Adolescent Self-Image; Princeton University Press: Princeton, NJ, USA, 1965.

83. Brazier, J.E.; Harper, R.; Jones, N.M.B.; O'Cathain, A.; Thomas, K.J.; Usherwood, T.; Westlake, L. Validating the SF-36 health survey questionnaire: New outcome measure for primary care. Br. Med. J. Gen. Pract. 1992, 305, 160-164. [CrossRef]

84. Wittchen H-UU. Reliability and validity studies of the WHO-Composite International Diagnostic Interview (CIDI): A critical review. J. Psychiatr. Res. 1994, 28, 57-84.

85. Weinreb, L.; Wehler, C.; Perloff, J.; Scott, R.; Hosmer, D.; Sagor, L.; Gundersen, C. Hunger: Its impact on children's health and mental health. Pediatrics 2002, 110, e41. [CrossRef] [PubMed]

86. Seligman, H.K.; Schillinger, D. Hunger and socioeconomic disparities in chronic disease. N. Engl. J. Med. 2010, 363, 6-9. [CrossRef] [PubMed]

87. Garner, A.S.; Shonkoff, J.P.; Siegel, B.S.; Dobbins, M.I.; Earls, M.F.; Garner, A.S.; Shonkoff, J.P. Early childhood adversity, toxic stress, and the role of the pediatrician: Translating developmental science into lifelong health. Pediatrics 2012, 129, e224-e231. [PubMed]

88. Bruening, M.; van Woerden, I.; Todd, M.; Laska, M.N. Hungry to learn: The prevalence and effects of food insecurity on health behaviors and outcomes over time among a diverse sample of university freshmen. Int. J. Behav. Nutr. Phys. Act. 2018, 15. [CrossRef] [PubMed]

89. Bruening, M.; Argo, K.; Payne-Sturges, D.; Laska, M.N. The struggle is real: A systematic review of food insecurity on postsecondary education campuses. J. Acad. Nutr. Diet. 2017, 117, 1767-1791. [CrossRef] [PubMed]

90. Farahbakhsh, J.; Hanbazaza, M.; Ball, G.D.C.; Farmer, A.P.; Maximova, K.; Willows, N.D. Food insecure student clients of a university-based food bank have compromised health, dietary intake and academic quality. Nutr. Diet. 2017, 74, 67-73. [CrossRef] [PubMed]

91. Bruening, M.; Brennhofer, S.; van Woerden, I.; Todd, M.; Laska, M. Factors related to the high rates of food insecurity among diverse, urban college freshmen. J. Acad. Nutr. Diet. 2016, 116, 1450-1457. [CrossRef] [PubMed]

92. O'Connell, M.E.; Boat, T.; Warner, K. Preventing Mental, Emotional, and Behavioral Disorders among Young People: Progress and Possibilities; National Academies Press: Washington, DC, USA, 2009. Available online: https:/ / www.ncbi.nlm.nih.gov /books /NBK32775/ (accessed on 27 June 2018).

93. Kessler, R.C.; Berglund, P.; Demler, O.; Jin, R.; Merikangas, K.R.W.E. Lifetime prevalence and age-of-onset distributions of DSM-IV disorders in the National Comorbidity Survey replication. Arch. Gen. Psychiatry 2005, 62, 593-602. [CrossRef] [PubMed]

94. Coates, J.; Swindale, A.; Bilinsky, P. Household Food Insecurity Access Scale (HFIAS) for Measurement of Food Access: Indicator Guide; FANTA III; Food and Nutrition Technical Assistance: Washington, DC, USA, 2007; Available online: https:/ / www.fantaproject.org/monitoring-and-evaluation/household-food-insecurityaccess-scale-hfias (accessed on 27 June 2018).

95. Hamelin, A.-M.; Habicht, J.-P.; Beaudry, M. Food insecurity: Consequences for the household and broader social implications. J. Nutr. 1999, 129, 525S-528S. [CrossRef] [PubMed]

96. Becker, C.B.; Middlemass, K.; Taylor, B.; Johnson, C.; Gomez, F. Food insecurity and eating disorder pathology. Int. J. Eat. Disord. 2017, 50, 1031-1040. [CrossRef] [PubMed]

97. Vandenbroucke, J.P.; Von Elm, E.; Altman, D.G.; Gøtzsche, P.C.; Mulrow, C.D.; Pocock, S.J.; Poole, C.; Schlesselman, J.J.; Egger, M. Strengthening the Reporting of Observational Studies in Epidemiology (STROBE): Explanation and elaboration. PLoS Med. 2007, 4, 1628-1654. [CrossRef] [PubMed]

98. Sterman, J.D. Learning from evidence in a complex world. Am. J. Public Health 2006, 96, 505-514. [CrossRef] [PubMed]

99. Mabry, P.L.; Marcus, S.E.; Clark, P.I.; Leischow, S.J.; M’Endez, D. Systems science: A revolution in public health policy research. Am. J. Public Health 2010, 100, 1161-1163. [CrossRef] [PubMed]

100. Friel, S.; Pescud, M.; Malbon, E.; Lee, A.; Carter, R.; Greenfield, J.; Cobcroft, M.; Potter, J.; Rychetnik, L.; Meertens, B. Using systems science to understand the determinants of inequities in healthy eating. PLoS ONE 2017, 12, e0188872. [CrossRef] [PubMed] 
101. Tarasuk, V. Implications of a basic income guarantee for household food insecurity. In Basic Income Guarantee Series; Research Paper No. 24; Northern Policy Institute: Thunder Bay, ON, USA, 2017; Available online: http: / / proof.utoronto.ca/wp-content/uploads/2017/06/Paper-Tarasuk-BIG-EN-17.06.13-1712.pdf (accessed on 27 June 2018).

102. Public Policy and Food Insecurity Fact Sheet. PROOF Food Insecurity Policy Research; Public Policy and Food Insecurity Fact Sheet: Toronto, ON, USA, 2016; Volume 41, Available online: http:/ / proof.utoronto.ca/wpcontent/uploads/2016/06/public-policy-factsheet.pdf (accessed on 27 June 2018).

103. Forget, E.L. The town with no poverty: The health effects of a Canadian income guaranteed annual income field experiment. Can. Public Policy 2011, 37, 283-305. [CrossRef]

104. American Academy of Pediatrics Council on Community Pediatrics, Committee on Nutrition. Promoting food security for all children. Pediatrics 2015, 136, e1431-e1438.

105. Tarasuk, V.; Cheng, J.; de Oliveira, C.; Dachner, N.; Gundersen, C.; Kurdyak, P. Association between household food insecurity and annual health care costs. Can. Med. Assoc. J. 2015, 187, E429-E436. [CrossRef] [PubMed]

106. Holben, D.H.; Marshall, M.B. Position of the academy of nutrition and dietetics: Food Insecurity in the United States. J. Acad. Nutr. Diet. 2017, 117, 1991-2002. [CrossRef] [PubMed]

107. McGorry, P.; Tanti, C.; Stokes, R.E.A. Australia's national youth mental health foundation-Where young minds come first. MJS 2007, 187, 5-8.

108. Pinto, A.D.; Bloch, G.; Bloch, G. Framework for building primary care capacity to address the social determinants of health. Can. Fam. Physician 2017, 63, 476-482.

(C) 2018 by the authors. Licensee MDPI, Basel, Switzerland. This article is an open access article distributed under the terms and conditions of the Creative Commons Attribution (CC BY) license (http:// creativecommons.org/licenses/by/4.0/). 